\title{
On the Date of Composition of Additions B and E to LXX Esther
}

\author{
Nikolaos Domazakis \\ Centre for Languages and Literature, Lund University, Lund, Sweden \\ nikolaos.domazakis@gmail.com
}

\begin{abstract}
Additions B and E to LXX Esther have been variously dated from the second century в СE to the first century CE. This study links the two Greek Additions, on the one hand, with Philo's writings through the concept of the "evil-hating justice" and, on the other hand, with the historical persons and events related to the Jewish-Alexandrian conflict of $38-41 \mathrm{CE}$, and dates their composition or final redaction to the early forties of the first century CE.
\end{abstract}

\section{Keywords}

Additions to Esther - Septuagint - Philo - Flaccus - Sejanus - Claudius

\section{Introduction $^{1}$}

The Septuagint version of the book of Esther (LXX Esther) includes six noncanonical Additions labelled A through $\mathrm{F}^{2}$ two of which, B and E, are universally considered to be not translations of Semitic texts but original Greek compositions penned by the same author. ${ }^{3}$ Addition B contains the text of a decree written in the name of King Artaxerxes by his vizier Haman, who orders

1 The author gratefully acknowledges the support of the Åke Wiberg Foundation through grant number H18-0188 in the preparation of this study. He also thanks the journal's two anonymous reviewers for their comments and suggestions.

2 In the present study we follow the versification and cite the Greek text of Esther according to Hanhart's Göttingen edition (Septuaginta: Vetus Testamentum Graecum, vol. 8.3 Esther).

3 See Martin, "Syntax Criticism," 69; Jobes, Alpha-Text of Esther, 26-27, 172-73. 
the extermination of the Jews of the Persian Empire. Addition E contains the text of another decree, this time written in the name of King Artaxerxes by the Jew Mordecai, Queen Esther's adoptive father, who becomes the new vizier after Haman falls from grace and is executed. This decree rescinds the king's former extermination order and allows the Jews of the Persian Empire to live according to their laws and customs.

The authorship and date of composition of Additions B and E have been much debated. Some scholars consider them to have been written, together with the other Additions, by Lysimachus, son of Ptolemy, who, according to the so-called colophon at the end of the LXX version (Add Esth F:11), produced in Jerusalem the Greek translation of the Hebrew book of Esther, which was then brought to Egypt "in the fourth year of the reign of Ptolemy and Cleopatra," namely, in 78/77 BCE, according to the prevailing scholarly opinion. ${ }^{4}$ Other scholars maintain that Additions B and E were written and integrated into LXX Esther at some later date in the first century BCE, by an author other than Lysimachus. ${ }^{5}$ Still others suggest that the two Additions may have originated not in LXx Esther but in a variant Greek version of the Esther story, namely, the Alpha Text $(\mathrm{AT})^{6}$ or the non-extant Greek Vorlage of the Old Latin (Vetus Latina) translation of Esther. ${ }^{7}$ Some of the dates that have been proposed for the composition of Additions B and E are: between 167 and $161 \mathrm{BCE} ;{ }^{8}$ before 13 о вСЕ ${ }^{9}$ between 126 and 116 вСЕ (the last decade of the reign

4 See Torrey, "Older Book of Esther," 27-28; Bickerman, "Notes," 248-50; Hanhart, Esther, 96; De Troyer, End of Alpha Text, 392, 398; Tov, "LXX Translation," 517, 519. On the date given in the colophon of LXX Esther, see Bickerman, "Colophon," 224-25.

5 See Moore, "Origins," 383-86; Daniel, Esther, Jeremiah, 165-66, 195. Moore argues that it is unlikely that the same author who exhibited a high mastery of Greek in composing Additions $\mathrm{B}$ and $\mathrm{E}$ would also have been responsible for the prosaic Greek in which the translation of the canonical text of Esther was couched and draws attention to a number of contradictions and inconsistencies between the Additions and the canonical portions of Esther (cf., e.g., Add Esth E:10 and Esth 3:1, 9:10; Add Esth E:18 and Esth 7:9-10, 9:6-10, 13-14), which would have been avoided if Lysimachus had authored Additions B and E.

6 See Jobes, Alpha-Text of Esther, 174, 224-25, 232. Jobes contends that the older form of Additions B and $\mathrm{E}$ is the one found in the Alpha Text, which may indicate that these two Additions were first introduced in the AT and were copied from there to the LXX. However, she is careful to point out that "the fact that the AT preserves the earlier form of additions $\mathrm{B}$ and $\mathrm{E}$ does not prove the direction of the copy. It means only that since the time when Additions B and E were copied, in whichever direction, they have experienced fewer changes in the AT than they have in the LXX. Though this data is consistent with the chronological priority of additions B and E in the AT, it does not prove it" (174).

7 See Haelewyck, "Texte dit 'Lucianique'," 13, 42; "Old Latin Version," 472-73.

8 Bardtke, "Zusätze zu Esther," 27.

9 Eissfeldt, Einleitung, 802. 
of Ptolemy VIII Euergetes II );10 between 120 and 100 BCE; ${ }^{11}$ before 114 BCE; ${ }^{12}$ between $114 \mathrm{BCE}$ and $94 \mathrm{CE} ;{ }^{13}$ end of the second century to the beginning of the first century BCE; ${ }^{14}$ between 103 and 76 BCE (reign of Alexander Jannaeus); ${ }^{15}$ shortly after the persecution of the Alexandrian Jews by Ptolemy Ix Lathyrus

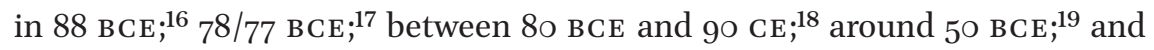
in the early Roman era. ${ }^{20}$ As regards the place of composition of these two Additions, many scholars assign them to Egypt on the basis of their "Egyptian flavour"21 and the similarities that they exhibit with 3 Maccabees, a book of undeniable Egyptian provenance. ${ }^{22}$

In this study we will argue for a date of composition or final redaction of Additions B and E to LXX Esther in the early forties of the first century CE. To this purpose we will adduce a combination of lexical, literary, and historical evidence.

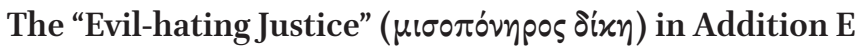 to LXX Esther and in Philo}

In Add Esth E:4, King Artaxerxes speaks of those wicked schemers-a hinted reference to Haman-who, puffed up by the boasts of those who are inexperienced in goodness, assume that they will escape the evil-hating justice of

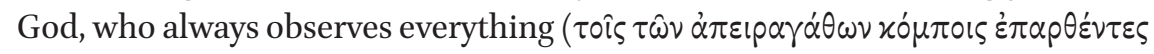

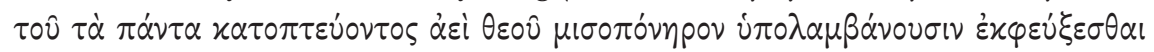

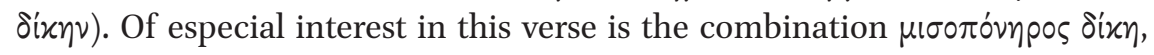
"evil-hating justice," which is not found in the other Greek versions of Esther. In the Alpha Text the two elements that make up this combination are not

\footnotetext{
$10 \quad$ Kottsieper, "Zusätze zu Ester," 124, 129.

11 Haelewyck, "Old Latin Version," 472-73.

12 Torrey, "Older Book of Esther," 26-28.

13 Moore, “Origins," 386; Daniel, Esther, Jeremiah, 165-66.

14 Passoni Dell'Acqua, "Liberation Decree," 76.

15 Bickerman, “Colophon," 233; “Notes," 259; De Troyer, End of Alpha Text, 392-93, 398.

16 Stein, "Essai d'adaptation," 110-11, 113-16.

17 Gardner, "Relationship of Additions," 3-4.

18 Gregg, "Additions to Esther," 669.

19 Motzo, "Autore e tempo," 245; "Rifacimento greco," 276-77; “Storia del testo," 213-14.

$20 \quad$ Wynn, Socio-Historical Contexts, 248.

21 See Gregg, “Additions to Esther," 665; Passoni Dell'Acqua, “Gli editti di liberazione,” 57-61; "Liberation Decree," 75-81.

22 See Moore, Daniel, Esther, Jeremiah, 195-99; Hacham, “3 Maccabees and Esther," 772-80.
} 


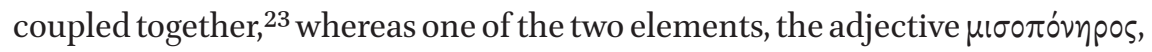
seems not to have occurred in the Greek Vorlage of the Vetus Latina of Esther and is missing in Josephus' paraphrase of Esther. ${ }^{24}$ In fact, the combination

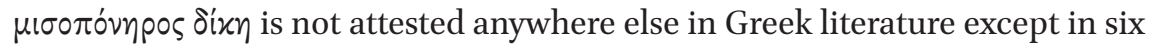
works of Philo ${ }^{25}$ and in a few late Byzantine authors. ${ }^{26}$

In his works Philo uses, aside from $\mu 1 \sigma 0 \pi$ óvnpos, several other nouns, adjectives, and participles as modifiers of $\delta^{\prime} i x \eta$, the personified Justice: $\alpha \dot{\delta} \varepsilon \dot{x} \alpha \sigma \tau ం \varsigma$

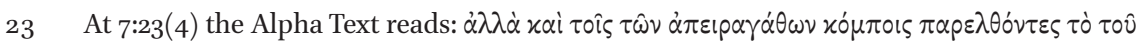

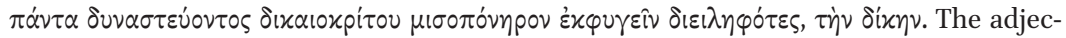

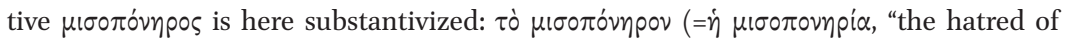
evil") is to be taken either as object of the infinitive $\dot{\varepsilon} x \varphi v \gamma \varepsilon \hat{\imath} v$, in which case $\tau \dot{\eta} \nu \delta^{\prime}(x \eta \nu$ is

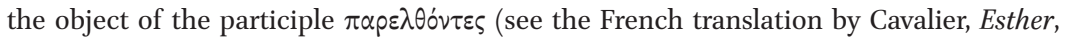
213-14: "mais aussi, négligeant la justice à cause des vantardises de ceux qui ignorent le bien et décidés à fuir la haine des méchants du juste juge qui dirige tout"), or, given the distance that separates $\pi \alpha \rho \varepsilon \lambda \theta \dot{v} v \tau \varepsilon \zeta$ from $\tau \dot{\eta} \nu \delta i x \eta \nu$, as object of the participle $\pi \alpha \rho \varepsilon \lambda \theta \dot{v} v \tau \varepsilon \varsigma$, in which case $\tau \dot{\eta} \nu \delta \dot{\nu} x \eta \nu$ is the object of the infinitive $\dot{\varepsilon} x \varphi v \gamma \varepsilon \hat{\imath} \nu$ (see the German translation by De Troyer and Wacker [Kraus and Karrer, Septuaginta Deutsch, 612]: "sondern im stolzen Prahlen derer, die vom Guten nichts wissen, sind sie auch noch davon überzeugt, sie könnten an dem Hass auf das Böse, der von dem alles gerecht beurteilenden Mächtigen (ausgeht), vorbeikommen und dem Gericht entfliehen"). The English translations of the Alpha Text by Clines (Esther Scroll, 241: "transgressing because of the boasts of those who know nothing of goodness, imagining that they will escape justice, the evil-hating attribute of the righteous Judge, who rules over all") and Jobes (NETS, 437: "gone astray due to the boasts of those who are inexperienced in goodness, they even imagine they will escape the evil-hating justice of the just Judge who rules all things") do not follow in this verse the grammatical construction of the Greek text.

24 At E:4 the Vetus Latina of Esther reads: dei semper omnia conspicientis malignitatem concipientes putant se evadere <iudicium> ("when they design an evil plan they think they will avoid the judgment of the god who always sees everything"; trans. Bellmann

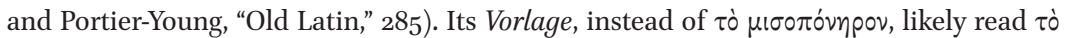

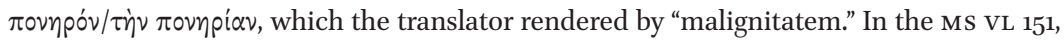
which is thought to be closest to the oldest, unrevised form of the Vetus Latina of Esther, the infinitive "evadere" lacks a complement; "iudicium" was supplied by the modern editor on the basis of the revised MSS VL 123 and 109. See Haelewyck, Hester, fasc. 1, 43.

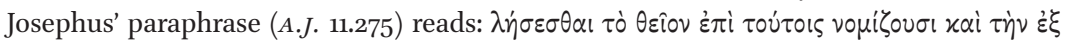

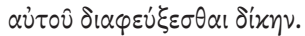

25 Philo, Conf. 128; Migr. 225; Mos. 2.53; Decal. 177; Spec. 3.140; Flacc. 107.

26 Ignatius Diaconus, Vita Nicephori, pp. 146.4 and 205.7 (de Boor); Philagathus, Homiliae, 22.6 (Rossi Taibbi); Demetrius Cydones, Epistulae, 436.30 (Loenertz); cf. Theophanes

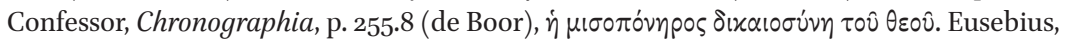
in his Ecclesiastical History (9.7.2), likely draws on Philo, when he writes that Justice with its "sleepless hatred of wickedness" followed close on the heels of Maximinus, a persecu-

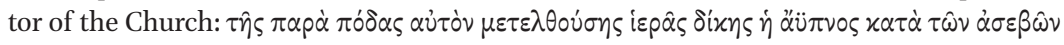

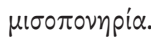




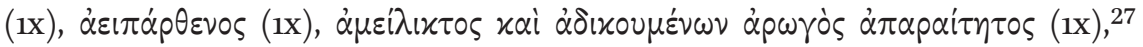

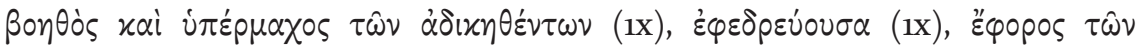

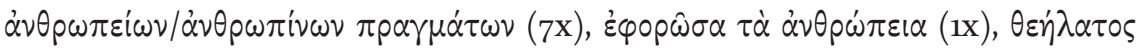

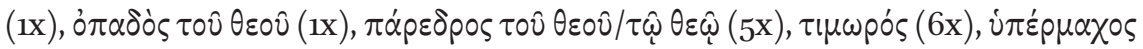

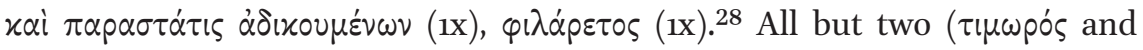

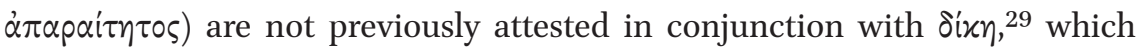
makes it likely that at least some of the combinations in which they occur in Philo's works, unless originating in literary works now lost to us, are originally Philonic.

The occurrence of $\mu 1 \sigma 0 \pi$ óvnpos $\delta i x \eta$ exclusively in Addition E to LXx Esther and in Philo allows us to wonder whether Philo might have drawn the combination from the former text. This does not seem very likely for a number of reasons:

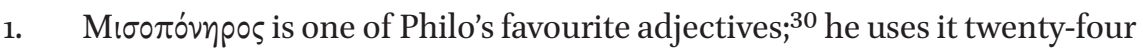
times, ${ }^{31}$ more than any other ancient author, whereas in the Septuagint it occurs only once, in Add Esth E:4.

2. As the juxtaposition of synonyms or antonyms is a favourite stylistic

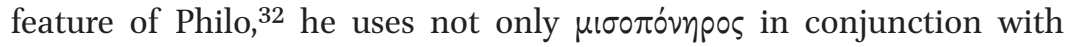

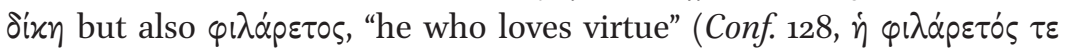

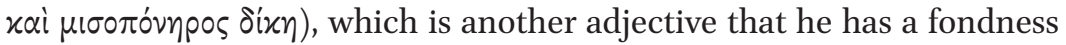
for, occurring sixty-four times in his works. He also uses the antonym of

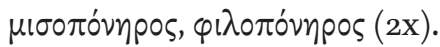

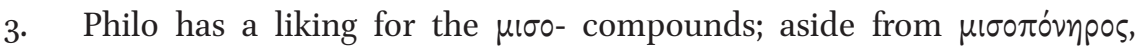

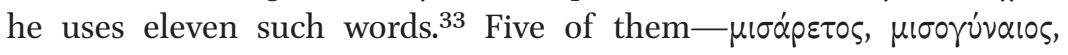

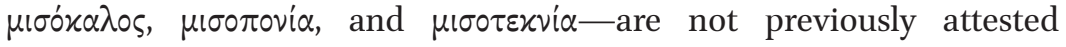
(although this does not mean that they were coined by Philo). ${ }^{34}$

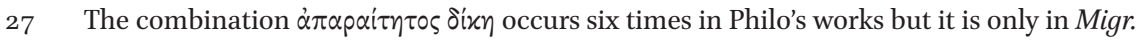
225 that $\delta^{\prime} x \eta$ is personified.

28 All the lexical searches in this study were carried out on the Thesaurus Linguae Graecae (TLG) online database.

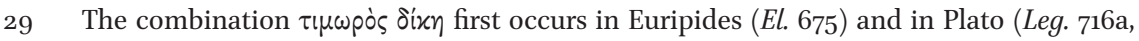
872e; Epin. 988e), and the combination $\dot{\alpha} \pi \alpha \alpha_{\alpha i} \tau \eta \tau 0 \varsigma \Delta i x \eta$ in a tragic adespoton (Tragicorum Graecorum Fragmenta, Adespota, fr. 495 Nauck) and in Demosthenes (1 Aristog. 11).

$30 \quad$ See van der Horst, Flaccus, 194.

31 Philo, Sacr. 28; Conf. 46, 49, 128, 131; Migr. 225; Mut. 108; Mos. 1.47, 149, 328; Mos. 2.9, 53, 167, 279; Decal. 87, 177; Spec. 1.55; Spec. 3.31, 75, 126, 140; Spec. 4.9; Flacc. 107; Legat. 193.

32 See Siegfried, Philo von Alexandria, ${ }^{132-35}$.

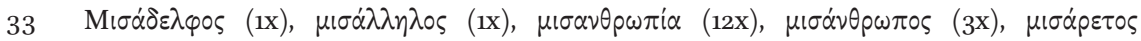

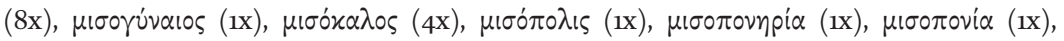
$\mu \iota \sigma 0 \tau \varepsilon \varkappa v i \alpha(1 \mathrm{x})$.

See Runia, "Verba Philonica," 313-14. 
4. All but two of the previously cited $\delta i x \eta$-combinations that Philo uses are, as far as we can tell from the extant ancient Greek sources, not borrowings from Jewish-Greek or secular Greek literature. The two

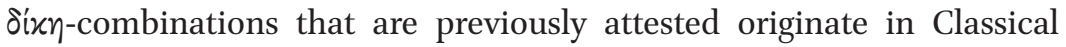
Greek and not in Jewish-Greek literature, septuagintal or otherwise.

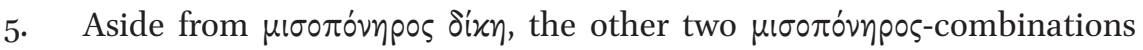

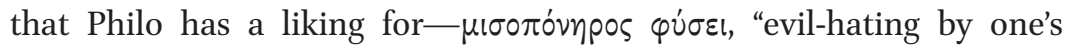

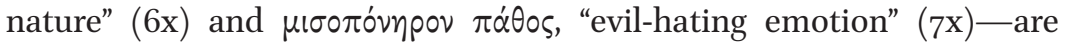
also previously unattested, and the same goes for some other combinations consisting of a $\mu$ ro- compound adjective and a noun such as

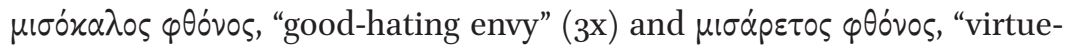
hating envy" (1x).

6. The use of a $\mu \sigma_{0}-/ \varphi i \lambda 0$ - compound adjective as modifier of a personified abstract concept is typical of Philo, as attested by such combinations as

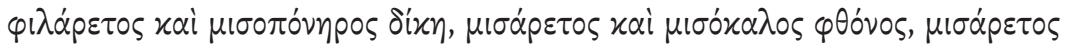

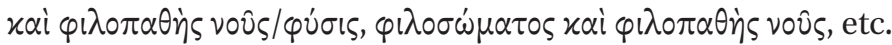

7. In his preserved works, Philo does not quote from or allude to the book of Esther. ${ }^{35}$

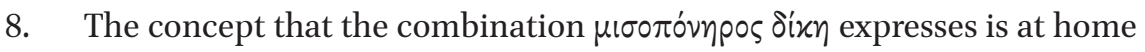
with Philo's theology, as we shall see further on.

It thus seems more likely that it was Addition E to LXx Esther, a text characterized by many intertextual borrowings, ${ }^{36}$ that drew the combination

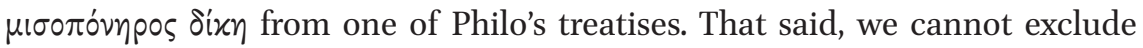
two other, less likely and, in any case, unprovable possibilities: that Philo may have known the Greek Esther and its Additions in their LXX version but, with

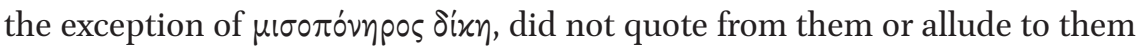
as, for example, Josephus was to do about half a century later; ${ }^{37}$ or, that both

35 See Ryle, Philo and Holy Scripture, xxvii, xxxi-xxxiii; Sterling, "Recherché or Representative," 12 n. 58: "There is no evidence that he [Philo] knew Esther, Ruth, Cant, Lam, or 2 Macc." Neither Leisegang, "Index locorum," nor Earp, "Scripture Index," list any reference or allusion in Philo's works to the book of Esther. According to the more recent Index of Philo's quotations from and allusions to the от (Allenbach et al., eds, Biblia Patristica,

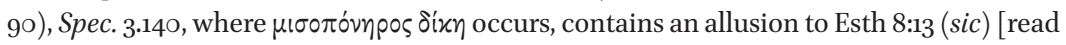
8:12 ${ }^{\mathrm{d}}$, Rahlfs/Add Esth E:4, Hanhart]. However, as we try to show above, the direction of the allusion most likely goes from Philo to the Addition E to LXx Esther rather than the other way around.

36 See Hacham, "3 Maccabees and Esther," 772-80.

37 See Cohen, Philo's Scriptures, 7 n. 21: "The fact that neither Philo, nor very many other Hellenistic authors, mention either Purim or the Book of Esther cannot be taken as proof that it was unknown to them-just that it was not relevant to the subjects of their extant writings." See also Sterling, "Recherché or Representative," 12: "His [Philo's] silence should not automatically be interpreted as ignorance since he rarely cited any text outside of 


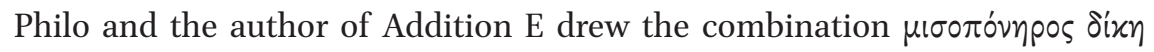
independently from a source unknown to us. ${ }^{38}$

If we pursue further the hypothesis that Add Esth E:4 is indebted to Philo for the above-discussed combination, we may attempt to date the latter's Philonic instances in order to set a terminus post quem for Addition E to LXx Esther. On the basis of Cohn's tentative classification and chronology of Philo's works,

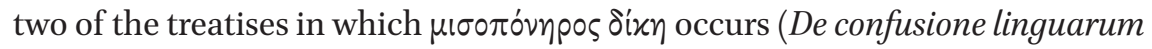
and De migratione Abrahami) are part of the Allegorical Commentary, two (De decalogo and De specialibus legibus 3) belong to the Exposition of the Law, and two (In Flaccum and De vita Mosis 2) belong to the Historical-Apologetic group of Philo's writings. Cohn argues that De specialibus legibus 3, In Flaccum, and likely De vita Mosis were written in the aftermath of the anti-Jewish disturbances that broke out in Alexandria in $38 \mathrm{CE}$ during the reign of Gaius Caligula, whereas the first sections of the Exposition of the Law, preceded by the Allegorical Commentary, were written at an earlier period. ${ }^{39}$ The earliest instances of $\mu 1 \sigma 0 \pi$ óvnpos $\delta$ ix $\eta$ in Philo's extant works seem thus to be found in the two treatises of the Allegorical Commentary, De confusione linguarum and De migratione Abrahami, which were likely written somewhere between the teens and the thirties of the first century CE. ${ }^{40}$

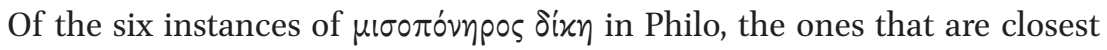
to Add Esth E:4 are Mos. 2.53, Decal. 177 , and Flacc. $107 .{ }^{41}$ In Mos. 2.53, justice

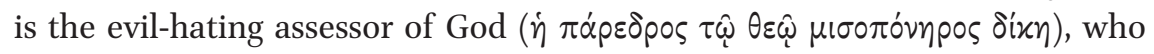

the Torah." The absence of God and of the religious element in the canonical Esther is a strong reason why Philo may have ignored it. See Bond, Pontius Pilate, 3o n. 28.

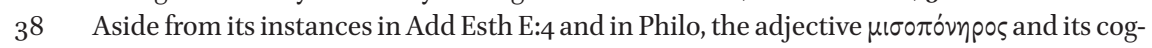

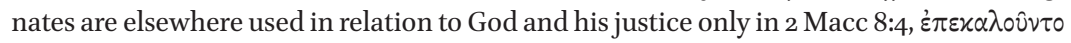

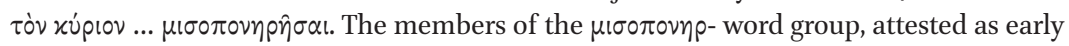
as the Attic orators, were likely transferred into the religious domain from the sphere of Ptolemaic judicial terminology, as they frequently occur in petitions from the Ptolemaic, and later the Roman, period, in which the petitioners appeal to the justice and the "hatred of wickedness" of a strategos or even of the king himself. See, e.g., P.Tarich. 13

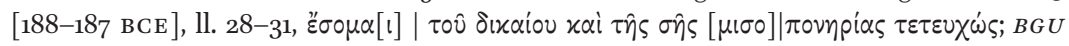

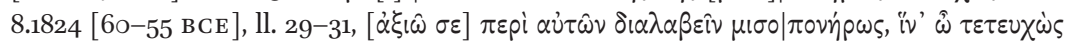

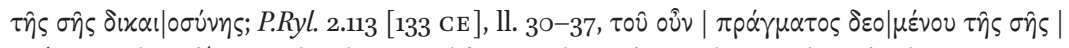

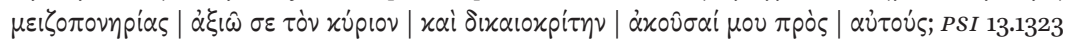

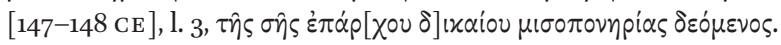

39 See Cohn, "Einteilung und Chronologie," 389, 421-24, 426-27, 433-34. See also Royse, "Works of Philo," 59-62, and Niehoff, Philo of Alexandria, 3-11 and 245-46.

40 See Niehoff, Philo of Alexandria, 245-46, who dates the Allegorical Commentary to ca. $10-35 \mathrm{CE}$ and the Exposition of the Law and the Historical Writings to ca. $40-49 \mathrm{CE}$.

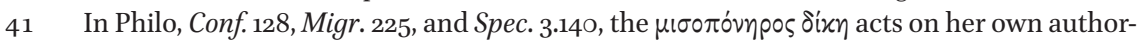
ity and is not associated with God as in Add Esth E:4. 
punishes those who practise knavery, injustice, and other vices, although God has bestowed on them an abundance of gifts such as good health, wealth, and glory; in Add Esth E:4, the evil-hating justice of God punishes those who, like Haman, show ingratitude toward and scheme against their benefactors, despite the honours that the latter have generously showered upon them. In

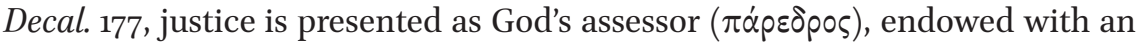

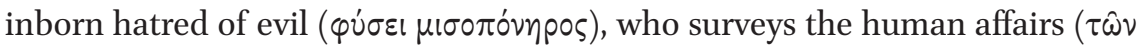
$\dot{\alpha} \nu \theta \rho \omega \pi i v \omega \nu$ है $\varphi \circ p \circ \varsigma \pi \rho \alpha \gamma \mu \alpha \dot{\tau} \tau \omega \nu)$ and punishes the wrongdoers and the sinners; in Add Esth E:4, the evil-hating justice is an attribute of God, who himself

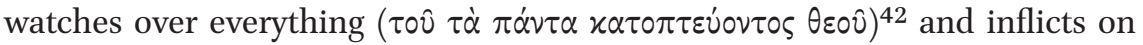
transgressors like Haman the punishment that they deserve (Add Esth E:18,

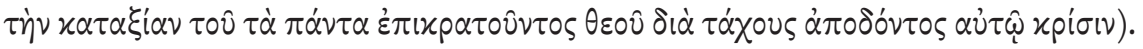
In Flacc. 107, the evil-hating justice punishes Flaccus, the Roman prefect of Egypt, who, like Haman in the book of Esther, was an enemy and persecutor of the Jews. As in Conf. 128, Migr. 225, and Spec. 3.140, and in difference from Add Esth E:4, the evil-hating justice in Flacc. 107 is a self-standing, personified hypostasis. Elsewhere in In Flaccum (104, 189), the personified justice is also self-subsistent and independent of God, yet in Flacc. 146 she is assigned the

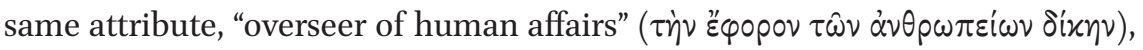

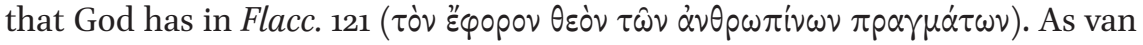
der Horst remarks, "Justice' is here, as elsewhere in Philo, nothing but a personified function of God."43

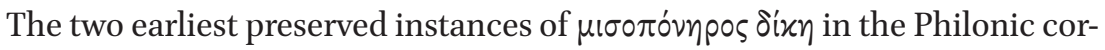
pus, which, as previously noted, seem to be found in Conf. 128 and in Migr. 225, do not exhibit any strong intertextual links with Add Esth E:4, as is the case with most of the later ones: in these two instances, the evil-hating justice is not presented as an assessor or an attribute of God, does not watch over human affairs, and does not punish a persecutor of the Jews. It thus seems unlikely

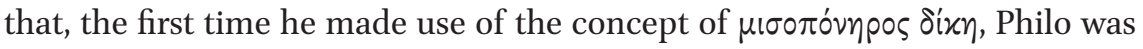
inspired by or intended to allude to Add Esth E:4.

Philo's concept of the personified Justice draws upon representations of the Greek mythological deity Dike, daughter of Zeus and Themis, in Hesiod,

42 The combination of the two attributes that God and his justice possess in Add Esth E:4"evil-hating" and "all-seeing" - is found elsewhere only in a third-century CE binding spell

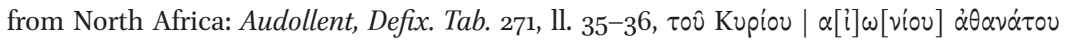
$\pi \alpha \nu \tau \varepsilon \varphi o^{\prime} \pi \tau 0 u \mu \varepsilon \varepsilon \sigma$

43 See van der Horst, Flaccus, 219-20. Cf. 191-92 and esp. 194: "Since in §102 and elsewhere it is God himself who takes revenge on Flaccus for his misdeeds, it is clear that in fact Dikê is nothing but God in his capacity of pursuer of justice." See also Borgen, "Two Philonic Prayers," 308. 
in Sophocles, in Plato, and in the Orphic hymn 62 (addressed to Dike), ${ }^{44}$ but is also informed by the Jewish conceptions of divine justice and the contemporary circumstances of the Jewish community in Alexandria. ${ }^{45}$ Foster points out that, in the Exposition of the Law, Philo presents Dike as the defender of the law and the punisher of its trespassers, whereas in the Allegorical Commentary and the Historical-Apologetic works Dike has the role of the avenger of the people of the law and the punisher of the enemies and persecutors of the latter. ${ }^{46}$ According to Foster, this shift reflects Philo's response to the anxieties and tribulations of the Alexandrian Jews at a time when their modus vivendi with the Greeks and the Romans was on its way to collapse. Philo may have conceived the exercise of judicial functions by God in tandem with the personified Dike as a counterpart to the judicial authority exercised by the Roman emperor and his prefect in Egypt:

Philo grasped this Greek hypostasis [Dike] and used it to express a hope in the kingship and rule of God; no matter how difficult life had become for the Alexandrian Jews he could advise them to hope with certainty in God's care and in Dike's vengeance. ${ }^{47}$... Philo constructed a theology that was parallel to the political power structure in Roman Egypt precisely because he and his community were not a part of that power structure. Philo used a Greek mythological personification of justice because it fit that system and made clear the hope he held of vindication against such an awesome opponent as the emperor. ${ }^{48}$

Scholarship has not failed to notice that Philo's In Flaccum shares with Esther and 2 Maccabees the motif of the just and retributive punishment of those who attack God and his people. When Flaccus is executed at Caligula's command, Philo comments that "it was the will of justice that the butcheries which she wrought on his single body should be as numerous as the number of the Jews

44 See Foster, Alexandrian Situation, 141-44, 176-89; Boyancé, "Écho des exégèses," 173-78.

45 Elsewhere in the LXX, justice appears personified in two deuterocanonical books, the Wisdom of Solomon (1:8; 11:20-22), which is of Alexandrian origin, and 4 Maccabees (4:13, passim). See Foster, Alexandrian Situation, 150-61.

46 See Foster, 120-21, 148, 162. It should be noted here that Foster considers the Allegorical Commentary to be chronologically posterior to the Exposition of the Law.

47 Foster, 136.

48 Foster, 148. Other scholars (Goodenough, By Light, 59-63; Boyancé, "Écho des exégèses," 175; Mendelson, "Philo's Dialectic," 114, 121) point out that Philo introduces Dike as an agent of punishment in order to exempt God from the responsibility to punish and partake in vengeance himself, as he is good and can only be the cause of good. 
whom he unlawfully put to death" (Flacc. 189 [Colson]). ${ }^{49}$ Likewise, Haman is hanged on the pole that he had prepared for Mordecai (Esth 7:10), and King Antiochus IV is seized with severe intestinal pains, "and that very justly, for he had tortured the bowels of others with many and strange inflictions" (2 Macc 9:6 NETS). According to Pelletier, the aforenamed books share three common themes, which are typical of the aretalogical genre: misfortune (e.g., illness or persecution), divine intervention, which reverses the situation, and recognition by humans of the intervention of God. In the case of persecution, the third theme is further developed into three phases: the defeated persecutor is not spared although he acknowledges his just punishment, those saved from persecution sing hymns in which they give thanks to God, and in some cases they celebrate an annual feast commemorating their victory (the latter element is missing in In Flaccum)..$^{50}$ Meiser and Borgen have pointed out further similarities between In Flaccum and 2 Maccabees, such as the striving to produce a pathopoeic effect, the all-knowing author's rendering of a character's inner thoughts (both characteristic, according to Meiser, of the "mimetic" historiography), the fictitious ante mortem speech and prayer (Flaccus) or vow and letter of repentance (King Antiochus IV) of the persecutor, and the emphasis on theodicy and on God's providence for his people. ${ }^{51}$

The above-named scholars do not claim, on the strength of the similarities that they adduce, that Philo was acquainted with Esther or with 2 Maccabees, although such claims have been made by other scholars. ${ }^{52}$ For the reasons that we previously gave, we consider it unlikely that Philo borrowed the combina-

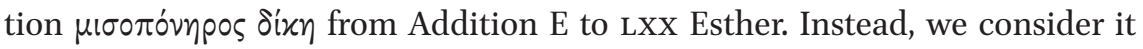
likely that the author of Addition E drew this combination from Philo, and more specifically from In Flaccum. If this is so, Additions B and E were written (or reached their final form) after the anti-Jewish pogrom launched in Alexandria in the summer of $38 \mathrm{CE}$, during Flaccus' prefectship, after Flaccus' execution in $39 \mathrm{CE}$, after the armed Jewish uprising in Alexandria that followed

49 See Pelletier, In Flaccum, 16-18; Borgen, "Two Philonic Prayers," 302-3, 307-8; "Philo's 'Against Flaccus,", 45, 53-54.

$50 \quad$ See Pelletier, 16-19; Borgen, "Two Philonic Prayers," 303; "Philo's 'Against Flaccus', 53.

$5^{1}$ See Meiser, "Gattung, Adressaten, Intention," 421-22, 427; Borgen, "Philo's 'Against Flaccus," $53-54$.

52 E.g., Zeitlin, "Agrippa," 29, argues that "Philo was influenced, no doubt, by the biblical book of Esther, by the books of Judith, and the Second and Third Maccabees. Philo makes Flaccus to repent in the end just as the author of the Second Maccabees makes Antiochus Epiphanes do." Bond, Pontius Pilate, 30-31, thinks that the portrait of Caligula in Philo's Legatio may have been modelled after that of King Antiochus IV in 2 Maccabees. See further references in Domazakis, Neologisms, 402-3. 
the death of Caligula in January $41 \mathrm{CE}$, and sometime after the publication of Philo's In Flaccum ( $4 \mathrm{O}$ or $41 \mathrm{CE}$ ) 53 and of Emperor Claudius' "Letter to the Alexandrians" (probably written in October $41 \mathrm{CE}$ and published in Alexandria on November 10, $41 \mathrm{CE}),{ }^{54}$ which was meant to settle the unrest in Alexandria.

There are strong analogies, on the one hand, between the persecution of the Jews in the Persian Empire under Artaxerxes' rule at the instigation of Haman, as described in Esther, and that of the Alexandrian Jews under Flaccus during the reign of Caligula, and, on the other hand, between Artaxerxes and Caligula's successor, Claudius. These analogies may have motivated an Alexandrian author in the early forties of the first century CE to supply the Greek translation of Esther with two Additions that could be easily read by his fellow Alexandrians, in the light of contemporary events, as texts à clef. We note below the most suggestive of these analogies as they emerge from a parallel reading of Additions B and E to LXx Esther, Philo's In Flaccum, and the letters that the emperor Claudius sent to Alexandria and Syria in the spring of $41 \mathrm{CE}$ (Josephus, A.J. 19.280-285), "to the rest of the world" shortly after the previous letter (Josephus, A.J. 287-291), and to Alexandria in the autumn of 41 CE (P.Lond. 6.1912): 55

1. In Additions B and E, King Artaxerxes appears especially concerned with establishing peace and stability in his kingdom and avoiding dis-

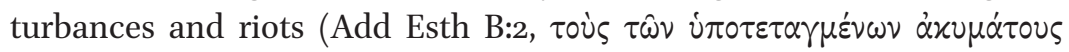

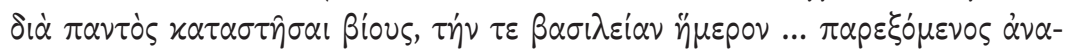

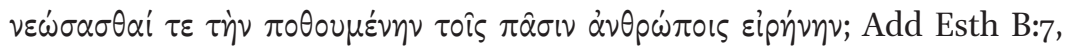

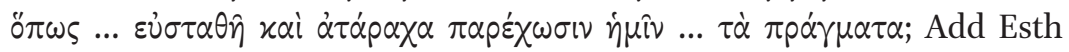

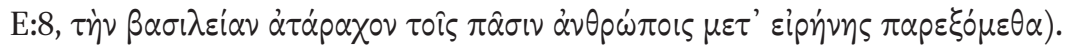
Likewise, in his letters to Alexandria, Claudius appears anxious to ensure

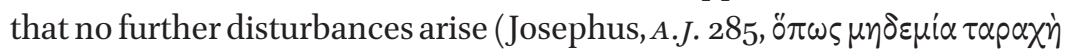

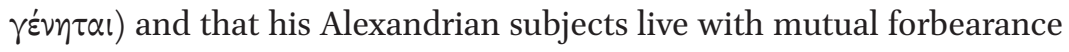

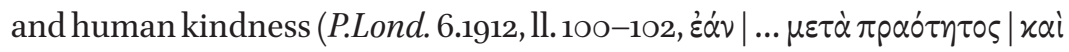

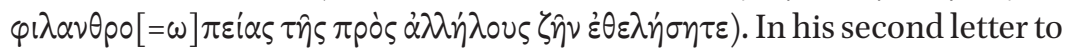
Alexandria, he even refers to a golden statue of the Pax Augusta Claudiana

53 See van der Horst, Flaccus, 4.

54 On the date of the letter, see Tcherikover, Fuks, and Stern, Corpus Papyrorum, 2:44.

55 The authenticity of the letters of Claudius transmitted by Josephus is a much-debated issue. See Pucci Ben Zeev, Jewish Rights, 303, 305-26, 333. 


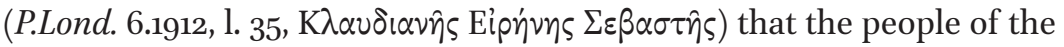
city voted to be erected in his honour and which he preferred instead to be set up in Rome. In the same year that he wrote this letter, the figure of Pax appeared on the reverse of his aurei, illustrating one of the central principles of his commencing reign, "Peace with gods and men."56

2. Both Artaxerxes and Claudius present themselves as being $\varphi$ i $\lambda \alpha \dot{v} \theta \rho \omega \pi 01$

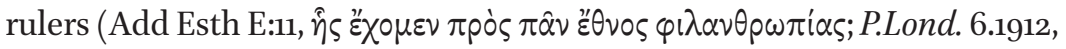
1. 81, $\dot{\eta} \gamma \varepsilon \mu \dot{\omega} \nu \varphi\left(\lambda \alpha \dot{\alpha} v \theta_{\rho} \circ[=\omega] \pi \circ \varsigma\right)$.

3. In Add Esth B:5, King Artaxerxes accuses the Jews of having an undermin-

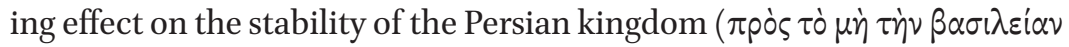

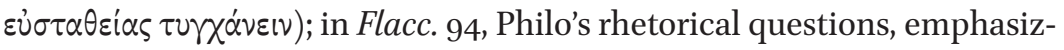
ing the peaceable character of the Jews and their contribution to the political stability of Alexandria, seem to echo a similar allegation ( $\pi \dot{0} \tau \varepsilon \delta$ '

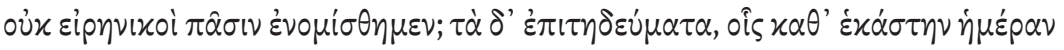

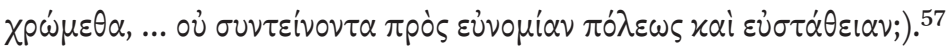

4. In their respective letters, Artaxerxes and Claudius permit the Jews to

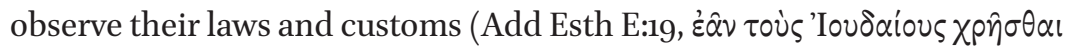

$5^{6}$ See Tcherikover, Fuks, and Stern, Corpus Papyrorum, 2:45-46. Rostovtzeff, "Pax Augusta," $25^{-28}$, argues that the figure depicted on the imperial coins was that of Pax-Nemesis, as was that of the golden statue that the Alexandrians wanted to erect in honour of Claudius. The statue, according to this scholar, was meant to commemorate the peace that Claudius re-established in Alexandria by suppressing the riot that the Jews had initiated in the city after the death of Caligula. Fearing that the erection of such a statue would kindle new Jewish disturbances, as it would imply that the hybris of the Jews was punished by Nemesis, Claudius asked that it be set up in Rome instead of in Alexandria. For a critique of this suggestion, see Tcherikover, Fuks, and Stern, 2:45-46. See also Hornum, Nemesis, 15-17.

57 Cf. Claudius' warning, in his second letter to Alexandria, that if the Jews do not obey his order not to bring in other Jews from Syria or Egypt, he will punish them for "fomenting

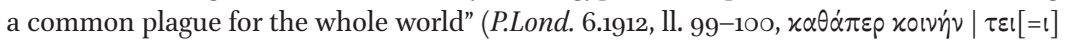

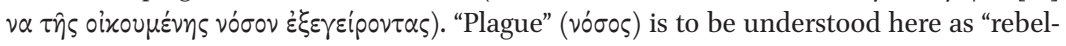
lion." See van der Horst, Flaccus, 184. Cf. also a fragment of the Acta Isidori et Lamponis (Tcherikover, Fuks, and Stern, Corpus Papyrorum, 2:no. 156c), which contains a discussion that presumably took place in $41 \mathrm{CE}$ between Isidorus, gymnasiarch of Alexandria and one of the leaders of the anti-Jewish faction, T. Claudius Barbillus, and the Jewish king Agrippa I. In it, Isidorus accuses the Jews of wishing to stir up riots in the entire

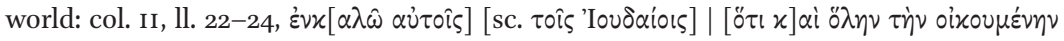

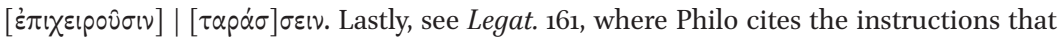
Tiberius sent to the governors throughout the Roman Empire, after the death of the purportedly anti-Semite prefect of the praetorian guard, Sejanus, in $31 \mathrm{CE}$. The instructions stated that they were to regard the Jews as being of peaceable disposition and their laws

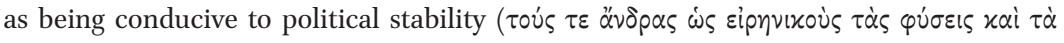

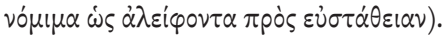




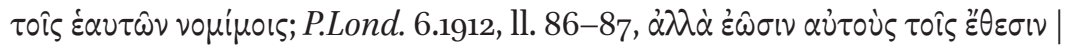

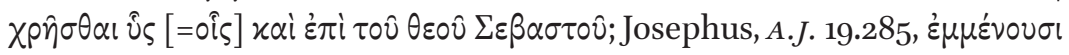

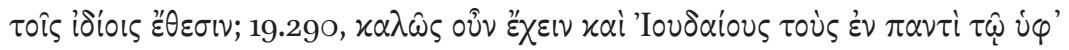

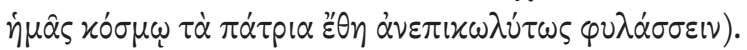

5. Haman was one of the "Friends" of King Artaxerxes (Add Esth E:5; cf. Esth 3:1); Flaccus was one of the "Friends" of Emperor Tiberius (Flacc. 2, 158). ${ }^{58}$ Haman was "second to the king" (Add Esth B:3, E:11) in the Persian kingdom; Flaccus, as praefectus Aegypti (Flacc. 152, 163), was second in authority to the emperor in one of the most important provinces of the Roman Empire. ${ }^{59}$ Haman planned to destroy all the Jews in Artaxerxes' kingdom

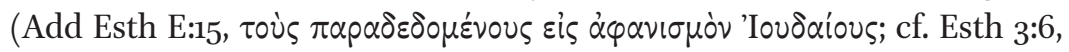
13); Flaccus, according to Philo, intended to utterly destroy the Jews of

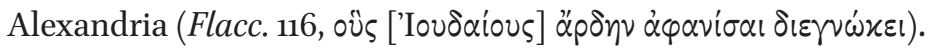

6. In Add Esth E:10 (as well as in LXx Esth 9:24), Haman is designated as Macedonian (M $\left.\alpha x \varepsilon \delta \omega^{\omega} v\right)$, although in LXx Esth 3:1 and 9:10, and in Add Esth A:17, he is called Bougean (Bouraios). ${ }^{60}$ In Add Esth E:14, he is even accused of contriving to bring the Persians under the domination of the Macedonians. This is a pseudo-historical allusion to the Macedonian conquest of the Persian Empire in the fourth century BCE, yet, as Foster notes, "in his circumstance, the writer [the author of Addition E] felt that a Macedonian was as anti-Jewish as Haman, and as hated an enemy

$5^{8}$ See Box, In Flaccum, 69; van der Horst, Flaccus, 91-92.

59 See van der Horst, 92.

6o Some scholars have linked Haman's alleged intention to assassinate Artaxerxes (Add Esth E:12) with the assassinations of Artaxerxes III Ochus in 338 вСЕ and his son, Artaxerxes IV Arses, in 336 всE, as well as with the attempted assassination of Darius III, by the eunuch Bagoas, whose position in the court of the aforenamed Achaemenid kings was comparable to that of Haman in the court of Artaxerxes in the story of Esther. According to Diodorus Siculus, Bagoas was a chiliarch in the court of Ochus (17.5.3); he was the king's most trusted friend (16.47.3-4) and the true "master of the kingdom" (16.50.8). According to Aelian, Var. hist. 6.8, he was an Egyptian, just like Haman, in Add Esth E:10, is said not to have been of Persian blood. Jobes, "Assassination," and more recently Silverstein, Veiling Esther, 127-34, have seen in the epithet "Bougean" used of Haman in LXX Esther an oblique reference to this Bagoas as well as to a certain Bagoses, who, according to Josephus, A.J. 11.297, was a general or governor of an Artaxerxes (Artaxerxes II Mnemon or, less likely, Artaxerxes III Ochus; in the latter case, he is to be identified with the Bagoas mentioned by Diodorus Siculus), who defiled the temple and imposed tribute on the Jews. Although it seems possible that the Greek translator of Esther intended to associate Haman with Bagoas/Bagoses, it is to be pointed out that the author of Lxx Addition E chose to make a different association, as he supplanted the appelation "Bougean" with "Macedonian" (unlike the composer of the Alpha Text, who at 7:25(10) calls Haman "Bougean"). 
as Haman."61 "Macedonian" seems to be used here metonymically for "Greek" and may be meant to allude to Flaccus' siding with the antiJewish Alexandrian Greeks. ${ }^{62}$

7. Haman is characterized as insolent (Add Esth E:2, $\mu \varepsilon \hat{\zeta} \zeta 0 v \dot{\varepsilon} \varphi p o ́ v \eta \sigma \alpha v ;$ E:3,

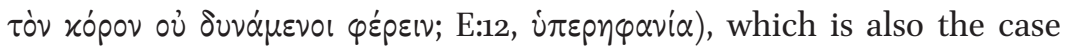

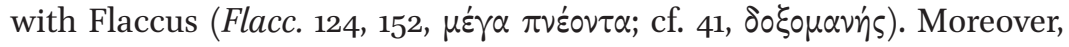
Haman is said to have been puffed up by the boasts of those who are

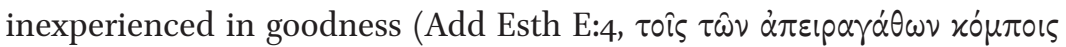
$\varepsilon \dot{\varepsilon} \alpha \rho \theta \varepsilon v \tau \varepsilon \varsigma)$. This statement has no correspondence to the canonical text of Esther, unless the author of Addition E wanted to insinuate that Haman was misled by the two chief bodyguards who sought to kill King Artaxerxes (Esth 2:21; cf. Add Esth A:17). However, the author of Addition E may have meant it as an allusion to Flaccus, who, according to Philo, was carried away by his former enemies, Dionysius, Isidorus, and Lampo, leaders of the Greek anti-Jewish party and "devisers of evils" (Flacc.

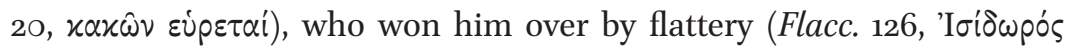

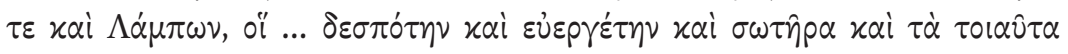

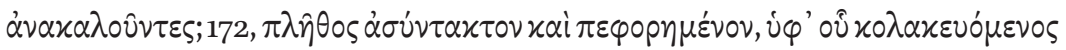
$\left.\delta \delta v \sigma \tau u x \dot{\zeta} \varsigma \dot{\eta} \pi \alpha \tau \omega^{\prime} \mu \eta \nu\right)$. Furthermore, in Add Esth E:5 King Artaxerxes states that many rulers, duped by the persuasiveness of "friends" to whom they

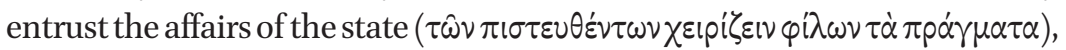

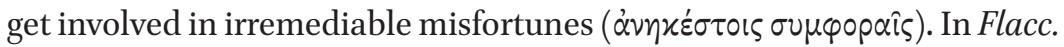
105, Philo expresses a similar idea in similar terms: during the reigns of

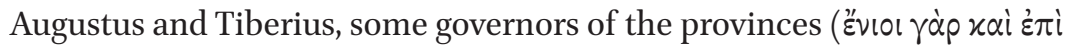

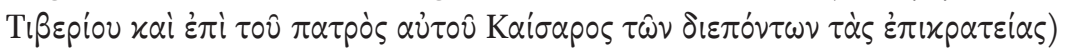

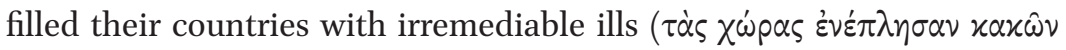
$\dot{\alpha} \nu \eta x \varepsilon \dot{\sigma} \tau \omega \nu)$.

We will go a step further and argue that the author of Additions B and $\mathrm{E}$ hints at events that occurred not only during Flaccus' prefectship but also earlier, during the period when another Roman high official, Sejanus, is said to have taken anti-Jewish measures.

Sejanus had an astonishingly rapid rise to power in the teens and twenties of the first century CE. ${ }^{63} \mathrm{In} 15 \mathrm{CE}$ he was appointed by Tiberius as praetorian prefect. In $26 \mathrm{CE}$ he saved the emperor's life and gained his unreserved trust.

$61 \quad$ Foster, Alexandrian Situation, 41-42.

62 On the term "Macedonian" used in an Alexandrian context, see Tcherikover, Fuks, and Stern, Corpus Papyrorum, 1:14-15, 24, 47. See also Stein, "Essai d'adaptation," 111-13, and Wynn, Socio-Historical Contexts, 237-39.

63 On the rise and fall of Sejanus, see Bird, "L. Aelius Sejanus," and Champlin, "Seianus Augustus." 
When Tiberius moved to Capri a year later, Sejanus became the most powerful man in Rome and was treated as if he were the princeps. ${ }^{64}$ The emperor made him adviser and assistant in all matters ${ }^{65}$ and termed him his "partner in toil" (socius laborum) and "assistant in power" (adiutor imperii). ${ }^{66} \mathrm{In} 31 \mathrm{CE}$ Sejanus was named consul together with Tiberius (consulatus socius) and was even promised to share the tribunicia potestas with the emperor, which would render him co-ruler of the empire and Tiberius' successor. ${ }^{67}$ The honours that he received included the erection of numerous statues of him, so that his face was "number two in the whole world." 68 At the height of his power, he was accused by Tiberius of plotting a conspiracy against him and was executed in October $31 \mathrm{CE}$, followed by his children and adherents. His name and memory were blackened, as testified by an inscription from Umbria, which calls him a "most pernicious enemy of the Roman people." 69

Josephus, Tacitus, Suetonius, and Dio Cassius inform us about a number of anti-Jewish measures that Tiberius took in Rome in $19 \mathrm{CE}$ : he abolished the Jewish rites and obliged the Jews to burn their religious vestments and other accessories; he expelled the Jewish community from the city, drafting four thousand Jews for military service in Sardinia; he threatened those who refused to obey with so heavy a punishment as enslavement. ${ }^{70}$ The aim of these measures, the inspiration of which has been assigned by some scholars to Sejanus, ${ }^{71}$ was probably to put a stop to the growing proselytism of Roman citizens to the Jewish faith. ${ }^{72}$ Philo accuses Sejanus of attacking through "false slanders" the Jews of Rome and of orchestrating a persecution of the Jews in the provinces,

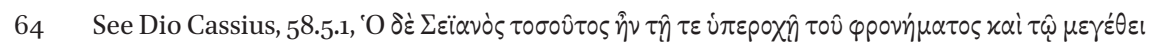

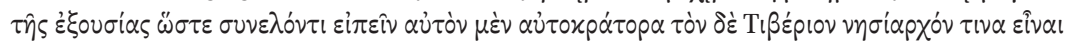

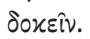

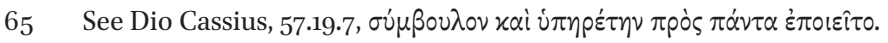

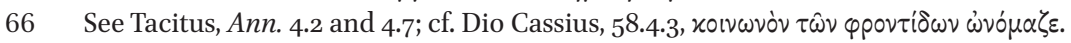

67 See Maier, "Sejanus," 10-11; Champlin, "Seianus Augustus," 364.

68 Juvenal, Sat. 10.63, ex facie toto orbe secunda. See Champlin, 373.

69 ILS 157: Providentiae Ti. Caesaris Augusti nati ad aeternitatem | Romani nominis, sublato hoste perniciosissimo p. R.

70 Suetonius, Tib. 36; Tacitus, Ann. 85; Josephus, A.J. 18.83-84; Dio Cassius, 57.18.5a. Unlike the other historians, Josephus dates these anti-Jewish measures to ca. $30 \mathrm{CE}-$ erroneously, it seems. See Smallwood, "Some Notes," 314-15, 326.

71 See Box, In Flaccum, 68. But see Smallwood, "Some Notes," 324-25; Legatio ad Gaium, $243-44$.

72 See Smallwood, “Some Notes," 319-22. 
which he did not have the time to carry out, shortly before $31 \mathrm{CE} .{ }^{73} \mathrm{His}$ persecution, according to Philo, aimed at destroying the entire Jewish nation - a grave accusation, which is not supported by other sources except Eusebius, who is, however, dependent on Philo. ${ }^{74}$ The Alexandrian philosopher even considers Flaccus - who was appointed praefectus Aegypti by Tiberius a year after the execution of the praefectus praetorio-as the continuator of Sejanus' antiJewish policy, ${ }^{75}$ and recounted the latter's persecution in a now lost prequel to his treatise In Flaccum. ${ }^{76}$

Tiberius' anti-Jewish policy changed drastically as soon as Sejanus was removed from the political scene. Philo again informs us that, after Sejanus' demise in $31 \mathrm{CE}$, Tiberius

charged his procurators in every place to which they were appointed to speak comfortably to the members of our nation in the different cities, assuring them that the penal measures did not extend to all but only to the guilty, who were few, and to disturb none of the established customs but even to regard them as a trust committed to their care, the people

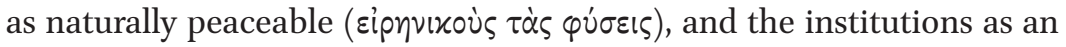
influence promoting orderly conduct ( $\varepsilon \dot{v} \sigma \tau \dot{\alpha} \theta \varepsilon 1 \alpha v)$.

Philo, Legat. 161 (Colson)

73 Philo, Legat. 159-160: "And indeed it was the same under Tiberius though matters in

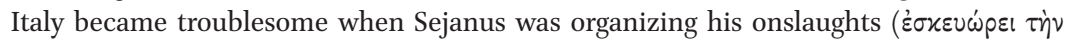
$\dot{\varepsilon} \pi(\theta \varepsilon \sigma l v)$... For Tiberius knew the truth, he knew at once after Sejanus's death that the accusations made against the Jewish inhabitants of Rome were false slanders,

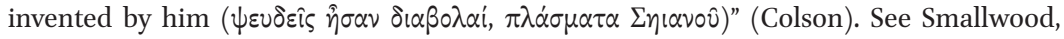
"Some Notes," 323 .

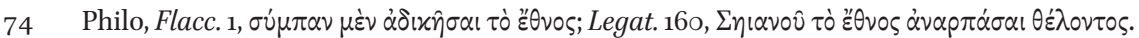

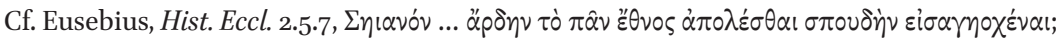
Chron. p. 176 (Helm), Seianus praefectus Tiberii, qui apud eum plurimum poterat, instantissime cohortatur ut gentem Iudaeorum deleat. In the same context, Eusebius mentions Pontius Pilate's attack on the Jews in Judaea in the latter part of the second decade of the first century CE, which may be taken to imply that Pilate was implementing Sejanus' antiJewish policy. See discussion in Smallwood, "Some Notes," 324, 326-28; Maier, "Sejanus," 9-10; Hennig, L. Aelius Seianus, 16o-79; van der Horst, Flaccus, 89-9o.

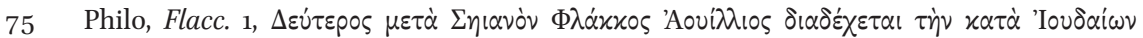

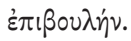

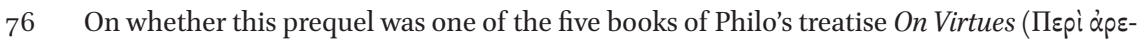
$\tau \hat{\omega} v)$, which dealt with the fortunes of the Jews under Gaius Caligula and also included the Legatio, or a now lost section of In Flaccum, that preceded the text that has come down to us, see Box, In Flaccum, xxxiii-xxxvii; Smallwood, Legatio ad Gaium, 38-43; Hennig, L. Aelius Seianus, 164-69; van der Horst, Flaccus, 5-6, $5^{\circ}$. 
We can easily draw correspondences between the above-mentioned persons and events and the ones figuring in Additions B and E to LXX Esther. Sejanus was the emperor's counsellor and, having saved his life, he enjoyed his complete confidence. Similarly, in Add Esth B:3, Haman is said to have been one of the king's counsellors ${ }^{77}$ and to have proven his firm loyalty to him

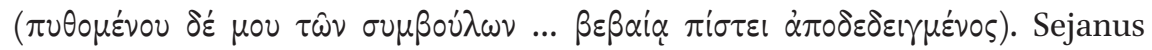
became Tiberius' second-in-command and practically his co-ruler just like Haman, in Additions B and E, is said to have been second to the king (Add

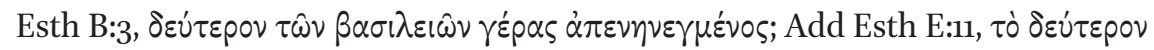

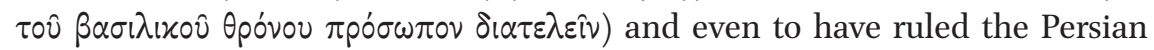

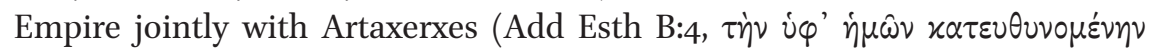

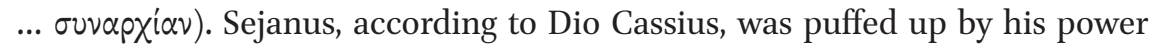
just like Haman was, according to Addition E. ${ }^{78}$ Moreover, like the biblical villain, Sejanus was an enemy and potential exterminator of the Jews (cf. Add

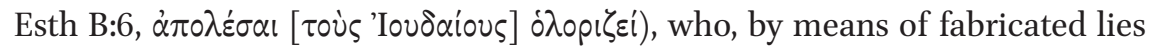

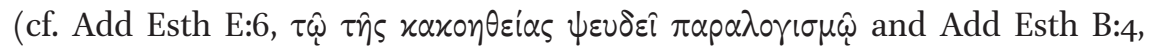
which enumerates the slanders against the Jews that Haman imparted to King Artaxerxes), launched an attack on the Jews of the Roman Empire, perhaps by issuing anti-Jewish decrees that did not have the time to be carried out due to his arrest and execution, or that were eventually overturned ${ }^{79}$ (cf. Addition B, which purports to be a copy of the letter calling for the extermination of the Jews that Haman sent in the name of King Artaxerxes to the provinces of the Persian Empire). In Legat. 16o, Philo suggests rather implausibly that Sejanus' slanders aimed at alienating Tiberius from the Jews, who would be his sole defenders in case he fell victim to his praetorian prefect's plots and treachery. ${ }^{80}$ Similarly, in Add Esth E:13-14, King Artaxerxes states that, by scheming against the Jews, Esther, and Mordecai, Haman aimed at isolating him $(\lambda \alpha \beta \dot{\omega} \nu \dot{\eta} \mu \alpha \hat{\varsigma}$

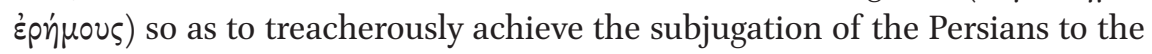
Macedonians. ${ }^{81}$ Furthermore, Sejanus was accused, perhaps without incon-

77 In the canonical Esther, Haman is named among the seven eunuchs who attended the king (Esth 1:10) but not among his counsellors (Esth 1:14).

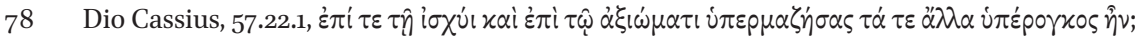

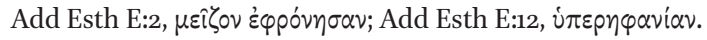

79 See Box, In Flaccum, 68: "According to this passage [Legat. 159-161] accusations had already been brought against the Dispersion in Rome, and apparently decrees of a drastic nature were about to be promulgated in all the provinces when Sejanus fell."

8o "He [Sejanus] wished to make away with the nation [of the Jews], knowing that it would take the sole or the principal part in opposing his unholy plots and actions, and would defend the emperor when in danger of becoming the victim of treachery" (Colson).

81 See Stein, "Essai d'adaptation," 112 n. 4. 
testable proof, ${ }^{82}$ of conspiring to overthrow and assassinate Tiberius, ${ }^{83}$ just as Haman was accused of plotting to assassinate Artaxerxes and usurp his throne

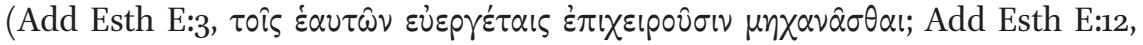

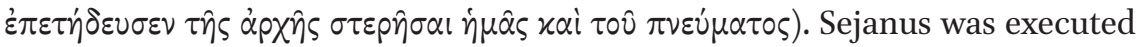
and his sons and associates were also put to death shortly after, while his name was exposed to infamy. Such was the fate met by Haman, too (cf. Add

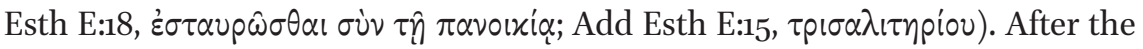
death of Sejanus, Tiberius adopted a non-aggressive policy towards the Jews and sent letters to his procurators throughout the empire instructing them to show proper regard for the Jewish laws, as they promoted the stability of the state. Likewise, after Haman's execution, King Artaxerxes communicated to his satraps his new pro-Jewish policy, which absolved the Jews from the accusations laid against them and allowed them to live in accordance with their

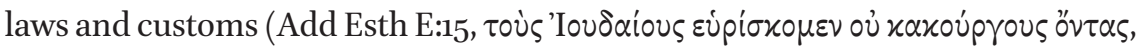

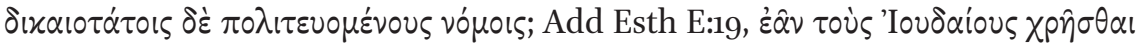

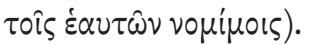

Artaxerxes' reference to his ouvapxia ("joint rulership") with Haman provides an especially strong clue for the identification of Haman with Sejanus, who was practically Tiberius' co-regent. The author of Additions B and E would have likely known that an Achaemenid despot would never have shared his power and that even a Ptolemaic or Seleucid monarch would have hardly coruled with a person other than a family member or used the term ouvapxia with regard to his $\dot{\varepsilon} \pi i \tau \hat{\imath} \nu \pi \rho \alpha \gamma \mu \alpha \dot{\tau} \tau \omega \nu$, "the one who is in charge of the affairs of the state" or "chief minister," as Haman is termed in Add Esth B:6. The fact that Artaxerxes' ovvapxi $\alpha$ does not involve Queen Esther, who, nevertheless, is

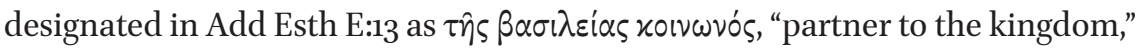
seems to allude to a type of rulership like that exemplified by Tiberius and Sejanus rather than to a Ptolemaic or Seleucid one. ${ }^{84}$ Artaxerxes' accusation that Haman contrived a conspiracy and an assassination plan against him —an

82 See Bird, "L. Aelius Sejanus," 88-92; Hennig, L. Aelius Seianus, 144-56; Champlin, "Seianus Augustus," 366 n. 13.

83 On Sejanus' alleged plan to murder Tiberius, see Tacitus, Ann. 6.8, consilia caedis adversum imperatorem. Valerius Maximus, a contemporary writer, speaks of Sejanus' attempted "parricide" (9.11, ext. 4, parricidii cogitatione).

84 It is to be noted that the term ouvapxi $\alpha$ occurs only in the Lxx version of Add Esth B:4. The corresponding verse in the Alpha Text uses the term $\mu$ ovapxi $\alpha$, "monarchy" [3:17(5)

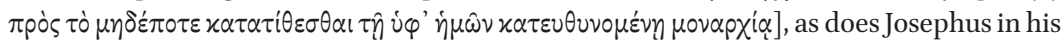

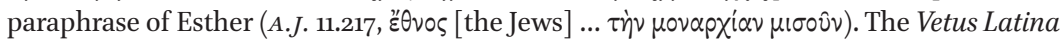
of Esther at B:4 reads: quod a nobis regitur ("what is decreed by us"; trans. Bellmann and Portier-Young, "Old Latin," 276). That the use of the "somewhat surprising" term ovvapxia "may suggest a display of modesty on the king's part," as Fox, Redaction, 53, maintains, is 
accusation that has no counterpart in the canonical Esther-provides another strong link between Haman's and Sejanus' lives and deeds, yet it has to be pointed out that the author of Addition E borrowed this dramatic element quasi-verbatim from 3 Maccabees, where King Ptolemy IV Philopator accuses his "Friends" of scheming to overthrow and kill him. ${ }^{85}$

If Philo's full account of Sejanus' anti-Jewish activity was preserved, and if the full text of Tiberius' letter to his provincial governors (which Philo summarizes in Legat. 161) had survived as was fortunately the case for Claudius' letter to the Alexandrians, we would be in a better position to assess whether Additions B and E allude to a universal threat posed to and overcome by the Jews in 28-31 CE.

In his doctoral dissertation entitled "The socio-historical contexts of the recensions of Esther" (1990), Wynn assigned Additions B and E to the Roman era, and more specifically to the period of tension between the Alexandrian Greeks and Jews, which culminated in the anti-Jewish pogrom in $38 \mathrm{CE}$, without, however, connecting them with Flaccus and with Philo's historical treatises. Wynn remarks that "Ahasuerus may be seen in parallel to the Roman emperor, Haman to the citizens of Alexandria, and Mordecai and Esther to the Alexandrian Jews" 86 and that "the temptation is to draw a parallel between Addition E and the letter of Claudius to the Alexandrians written in 41 C.E." He adds, however, that "some hesitancy must be held in regards to dating this recensional stage of Esther to such a late date" ${ }^{\prime \prime 7}$ and in his conclusion he confines himself to stating cautiously that "this text [the version of Esther which included the Additions B and E] probably reflects the conditions of the early Roman era but probably not as late as the persecution documented by Philo during the reigns of Gaius and Claudius (37 C.E.) [sic]." 88

De Troyer is another scholar who has referred to the above-discussed period in relation to Greek Esther-though not the Lxx version but the Alpha Text. She agrees with Bickerman that the translation of LXx Esther was made by Lysimachus in Jerusalem during the reign of Alexander Jannaeus (103-76 BCE) and that it included Addition E (and B), although she cannot establish with certainty whether Lysimachus composed these Additions, as Bickerman believes, or simply inserted them into his translation. She argues

\footnotetext{
rather unlikely, considering the authoritative tone of the king, who designates himself as "the master of the whole world" (Add Esth B:2).

86 Wynn, Socio-Historical Contexts, 238.

87 Wynn, 239.

88 Wynn, 248.
} 
that this version was the Vorlage of the Alpha Text, which was produced in Rome in 4O-41 CE, when a Jewish author, who may have been Philo, rewrote Lysimachus' version-Addition E included. ${ }^{89}$ According to De Troyer, in composing the Alpha Text, its author had "one specific person in mind,"90 namely, Herod Agrippa I, grandson of Herod the Great, who intervened to Caligula on behalf of the Alexandrian Jews, when the latter suffered under Flaccus, and on behalf of the Jerusalem Jews, when Caligula threatened to erect his statue in the temple, and who also urged Claudius to issue edicts in favour of the Jews in Alexandria, Syria, and the rest of the world. ${ }^{91}$ De Troyer holds that "Mordecai is to be identified with Agrippa I, Haman with Flaccus, the unstable governor of Alexandria, and king Ahasuerus with emperor Claudius" and that "the identity of the figure of Esther is not so easily established."92 In acknowledgement of the importance of the figure of Agrippa, she even proposes to call the Alpha Text "The Agrippa Text."93

Our position vis-à-vis the above two theories is as follows.

We share Wynn's opinion that Additions B and E were not part of Lysimachus' Greek version but belong to the last redactional stage of LXX Esther, which, despite Wynn's reservations, is to be dated to as late as shortly after $41 \mathrm{CE}$.

We accept (but with regard to Additions B and E to LXx Esther, not the Alpha Text) De Troyer's identification of Haman with Flaccus (and, we add, Sejanus) and of Artaxerxes, in Addition E, with Claudius (and, we add, possibly even Tiberius). In designating Mordecai as "saviour and perpetual benefactor" (Add

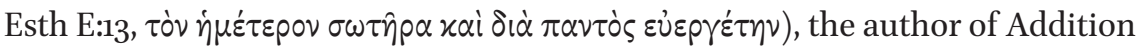
E may have had Herod Agrippa I in mind, ${ }^{94}$ yet this one and only reference to Mordecai in the two Additions does not allow us to further substantiate this connection, and what is more, the two epithets are not used in relation to the Jews but to King Artaxerxes, who was saved twice by Mordecai (Esth 2:22-23;

89 De Troyer, End of Alpha Text, 393, 396-98, 402.

90 De Troyer, 401.

91 See Philo, Flacc. 103; Legat. 179, 276-329; Josephus, A.J. 18.289-303, 19.278-291. Agrippa also protested to Petronius, the Roman governor of Syria, against a number of Greek youths who set up an image of Claudius in the synagogue of the Phoenician city Dora; Petronius reprimanded severely the leaders of the city and ordered that the perpetrators be brought before him to account for their actions (see Josephus, A.J. 19.300-311).

92 De Troyer, End of Alpha Text, 402.

93 De Troyer, 403.

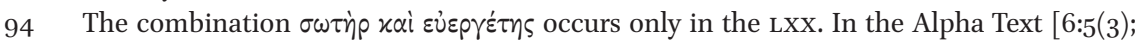
7:26(13)], Mordecai is designated only as $\sigma \omega \tau \eta \dot{p}$. Literary and epigraphical sources com-

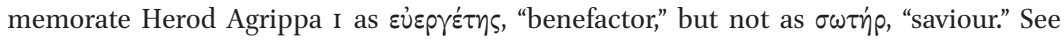
Marshall, Jesus, Patrons, Benefactors, 160-62, 165-70. 
Add Esth E:12-13) ${ }^{95}$ As for Queen Esther, her designation as "partner to the

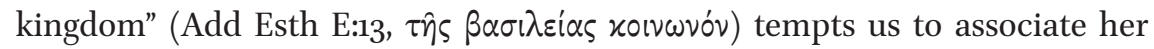
with Agrippina the Younger, Claudius' fourth wife. Tacitus gives us an idea of the empress striving for power when he presents her receiving obeisance from the captive British king Caratacus, seated on a dais next to that of the emperor, before the Roman standards. As Tacitus comments, "it was the advertisement of her claim to a partnership in the empire (imperii sociam), which her ancestors had created." ${ }^{\prime 96}$ The same historian further relates that Agrippina aimed at a partnership in the empire (consortium imperii) during the reign of her son, Nero, too. ${ }^{97}$ The term socia or consors imperii, which recalls the terms socius laborum and adiutor imperii that Tiberius used of Sejanus, is equivalent to the

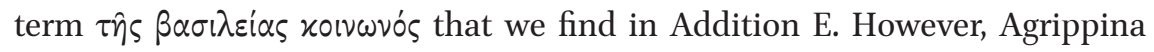
married Claudius in $49 \mathrm{CE}$, and Messalina, Claudius' third wife who was empress in $41 \mathrm{CE}$, is not known to have had the political ambitions of her successor. One should keep in mind, though, that Additions B and E are not free compositions, in which the author introduced his own fictitious characters in order to allude to contemporary historical figures; he had to use the characters of the Esther story, not all of which lent themselves to identification with reallife personages. Thus, one should not expect a one-to-one identification of all the characters that appear in Additions B and E with real historical figures.

If we accept with De Troyer that the Alpha Text is a rewritten form of Lxx Esther and that, in aggrandizing the role of Mordecai, its author had Agrippa I in mind, and if the date of composition or final redaction of Additions B and $\mathrm{E}$ that we suggest in this study holds true, we have to posit that the Alpha Text was produced shortly after the insertion of Additions B and E to Lxx Esther (given that, in the opinion of many scholars, the Alpha Text imported Additions B and E from the LXX text), ${ }^{98}$ and not long after $44 \mathrm{CE}$, when Agrippa died. Philo cannot have been the composer of the Alpha Text, inter alia, because at 7:23(4)

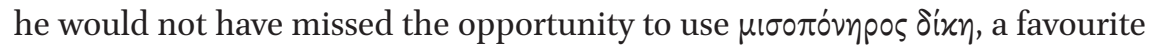
expression of his.

What we consider likely is that the author of Additions B and E was an Alexandrian, a contemporary of Philo, who lived through the plotted and

\footnotetext{
95 See Nock, "Soter and Euergetes," 720; Jung, $\Sigma \Omega T H P, ~ 234-36$.

96 Tacitus, Ann. 12.37.4 (Jackson).

97 Tacitus, Ann. 14.11.1.

98 See Moore, Daniel, Esther, Jeremiah, 165, 194; Clines, Esther Scroll, 72, 85-86, 140; Haelewyck, "Texte dit 'Lucianique'," 14, 40, 43; "Old Latin Version," 463; Fox, Redaction, 16. Cf. De Troyer, End of Alpha Text, 365: "The author of the AT did not consider Add. E as a text which was added to the Lxx but was familiar with and made use of the LXx including Add. E as his Vorlage."
} 
the attempted persecutions of the Jews in Alexandria and elsewhere under Tiberius and Caligula, between ca. 28 and $38 \mathrm{CE}$, and composed the two royal letters of Artaxerxes - with the specific intention of integrating them into the Greek translation of Esther, which was already supplied with the other four Additions-right after Claudius sent his letter to the Alexandrians in late $41 \mathrm{CE}$. This author cannot have been Philo, since a writer as accomplished as the Alexandrian philosopher would not have relied so heavily on 3 Maccabees as did the author of Additions B and E; ${ }^{99}$ yet he seems to have been acquainted with the treatise(s) that Philo had written on the persecutions of Flaccus and Sejanus and to have composed his two Additions so that the contemporary readers could easily draw the analogy between Haman, the villainous persecutor of the Jews in the Esther story, and the two Roman high officials. He also

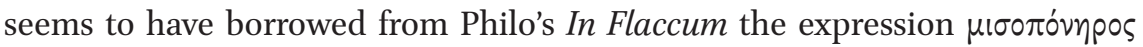
dixn (which might also have occurred in the treatise's lost prequel on Sejanus) that was likely meant to allude specifically to this Philonic work, in the same way that he seems to have borrowed from 2 Maccabees $(8: 34,15: 3)$ the adjec-

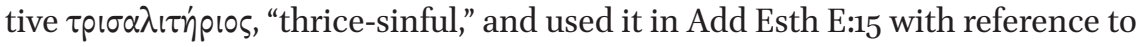
Haman in order to draw a connection between the latter and the anti-Jewish general Nikanor. ${ }^{100}$

That said, we cannot rule out the possibility that Additions B and E entered LXX Esther sometime after the composition of 3 Maccabees, the date of which cannot, however, be pinpointed with certainty, ${ }^{101}$ and were then retouched and recontextualized in the early forties of the first century CE by a redactor who wanted to allude to contemporary persons and events. ${ }^{102}$ In any case, the

99 On the similarities between the letters of King Artaxerxes in Additions B and E to Esther and the letters of King Ptolemy IV Philopator in 3 Maccabees, see Motzo, "Rifacimento greco e III Maccabei," 285-88; Moore, Daniel, Esther, Jeremiah, 195-99; Hacham, "3 Maccabees and Esther," 772-8o; Magliano-Tromp, "Egyptian Judaism," 6o-67.

100 See Domazakis, Neologisms, 236-44.

1013 Maccabees is usually dated to between 100 and 3 в вСЕ, although later dates have also been proposed. See Johnson, Historical Fictions, 129-41.

102 Another likely clue that the LXX version of Additions B and E was composed (or redacted to its final form) in the Roman period is the use of the term $\delta$ เ $\alpha \tau \dot{\alpha} \gamma \mu \alpha \tau \alpha$ (instead of $\pi \rho \circ \sigma \tau \dot{\alpha} \gamma-$ $\mu \alpha \tau \alpha$ that occurs in the Alpha Text) to designate the royal decrees in Add Esth B:4 ( $\tau \dot{\alpha} \tau \varepsilon \tau \hat{\omega} \nu$

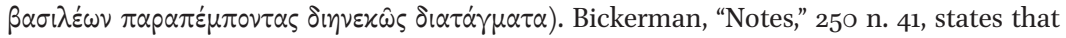

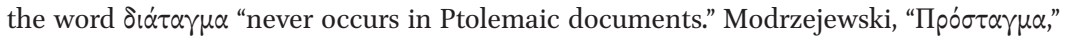
205-6, affirms that "the term $\pi \rho \sigma^{\sigma} \tau \alpha \gamma \mu \alpha$ appears in the papyri of the Ptolemaic epoch as a technical term for the definition of a special kind of royal ordinances which can assume the epistolary or the non-epistolary form ... In the Roman and Byzantine epochs this term is used to design[ate] the imperial edicts and the edicts of the prefect of Egypt (promis-

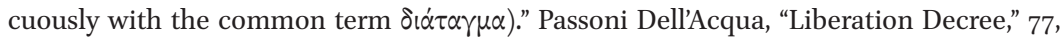
also states that $\delta \dot{\alpha} \tau \alpha \gamma \mu \alpha$ "takes on technical connotations for imperial decrees during the 
terminus post quem for the composition of Additions B and E to Esther can only be set by 3 Maccabees. ${ }^{103}$ If the latter book was composed as late as in the time of Caligula, as some scholars have posited, ${ }^{104}$ we may even venture to consider the possibility that its author also composed the two royal letters of Additions B and E to Esther, duplicating, so to speak, the two royal letters of King Ptolemy IV Philopator in 3 Maccabees (3:12-29 and 7:1-9).

\section{3}

\section{Conclusion}

Esther scholars contend that Additions B and E were written for the purpose of enhancing the "dramatic interest" and the "sense of authenticity" of the Esther

Roman age: during the Ptolemaic period it appears in the papyri with the sense of 'provision, order, decree' and does not seem to officially designate a royal decree." However, she points out that in Add Esth B:4 "the cod. B [Vaticanus] gives $\pi \rho \circ \sigma \tau \alpha \gamma \mu \alpha \tau \alpha$ in the first draft, with the $\pi \rho \circ[\sigma]$ - erased and $\delta(\alpha$ written over the erasure: this can be explained by the fact that, when the correctors were at work, the most common term was $\delta \dot{\alpha} \tau \alpha \gamma \mu \alpha$, and $\pi \rho \dot{-}-$ $\sigma \tau \alpha \gamma \mu \alpha$ might have seemed rather unusual and to be avoided." It should be noted, though, that, with the exception of the uncertain scriptio inferior in Vaticanus and the minuscule 249, all the textual witnesses of Lxx Esther read $\delta 1 \alpha \tau \alpha \gamma \mu \alpha \tau \alpha$; moreover, had the correctors of Vaticanus found the term $\pi$ pó $\sigma \alpha \gamma \mu \alpha$ in Add Esth B:4 "unusual and to be avoided," they would have changed it to $\delta \dot{\alpha} \tau \alpha \gamma \mu \alpha$ in the canonical sections of LXx Esther, where it

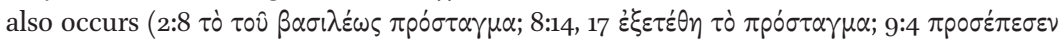

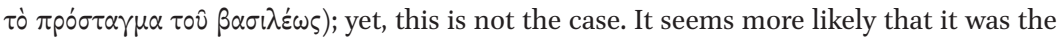
original scribe of Vaticanus who, in Add Esth B:4, found the term $\delta 1 \alpha \tau \alpha \gamma \mu \alpha \tau \alpha$ "unusual" and wrote $\pi \rho \circ \sigma \tau \gamma \mu \alpha \tau \alpha$ instead, because elsewhere in Lxx Esther the royal ordinances are designated as $\pi \rho \circ \sigma \tau \dot{\alpha} \gamma \mu \alpha \tau \alpha$, and that the first of the two correctors, who was contemporary with the scribe (possibly the diorthotes of the scriptorium), changed $\pi \rho \circ \sigma \tau \alpha \gamma \mu \alpha \tau \alpha$ to $\delta\llcorner\alpha \tau \alpha \gamma \mu \alpha \tau \alpha$, considering the latter to be the original reading in this particular verse-a correction retained by the scribe/corrector who re-inked the Codex in the tenth or eleventh century (on the correctors of Codex Vaticanus, see Metzger, Manuscripts, 74, and

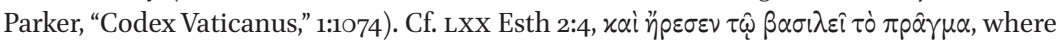
the reading of the original hand of Vaticanus is $\pi \rho \circ \sigma \tau \alpha \gamma \mu \alpha$, which the corrector changed to $\pi \rho \alpha \gamma \mu \alpha$ - the reading found in all the other Mss - by placing expunging dots above the letters ост. We also refer here to Dorothy, Books of Esther, 192, who maintains that the form of Addition B to Esther "evidences more affinities with a Roman decree than with a Hellenistic letter."

103 A discussion about whether Additions B and E originated outside of Egypt and underwent various redactional stages has to deal, inter alia, with the arguments advanced by Bickerman, "Notes," 249-50, concerning the "Seleucid flavour" of these two Additions. We take this discussion up in a forthcoming study.

104 See Grimm, Das zweite, dritte und vierte Buch, 220-21; Kopidakis, $\Gamma^{\prime}$ M $\alpha \varkappa \alpha \beta \alpha i \omega \nu, 31-34$; Collins, Athens and Jerusalem, 124-26. For counter-arguments, see Barclay, Jews, 203, and Johnson, Historical Fictions, 132-34. 
story ${ }^{105}$ according to the practice of Greek historiographers and authors of historical novels who quoted official documents in their works in order to "set forth vital points" of their narratives. ${ }^{106}$ Although one cannot deny that the two royal letters contained in Additions B and E to Esther served that purpose, it should also be considered that they might have arisen (or at least that their final form might have arisen) as a response to a contemporary historical situation, which, as we argued in this study, was the persecution and the subsequent reestablishment of the Jewish community in Alexandria in 38-41 CE. The same historical situation gave rise to Philo's treatise In Flaccum, whose anti-Jewish protagonist is punished by the same "evil-hating" divine justice that overtakes Haman, the villainous persecutor of the Jews, in Addition E to

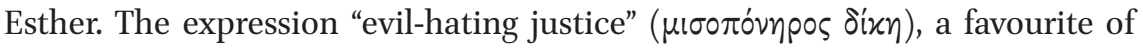
Philo, which elsewhere occurs only in Addition E to Lxx Esther, betrays the debt of the author of the latter text to the Alexandrian philosopher and allows us to glimpse the historical personalities that likely lie behind the biblical figure of Haman in Additions B and E: Flaccus, the Roman prefect of Egypt under Tiberius and Caligula, and possibly Sejanus, the all-powerful prefect of the praetorian guard under Tiberius, both of whom Philo, in his historical treatises, excoriates for persecuting the Jews. The letter of King Artaxerxes in Addition E, which rescinds his previous extermination order and allows the Jews to observe their own customs, was likely informed by the letters confirming the religious rights of the Jews that the emperor Claudius sent to Alexandria, Syria, and the rest of the Roman Empire in $41 \mathrm{CE}$ - and especially by the one he addressed to the Alexandrians in the autumn of that year. It is shortly after the publication of the latter letter that we are to place the composition (or the final redaction) of Additions B and E to LXx Esther.

\section{Bibliography}

Allenbach, Jean, et al., eds. Biblia Patristica. Supplément: Philon d'Alexandrie (Paris: Centre National de la Recherche Scientifique, 1982).

Barclay, John M.G. Jews in the Mediterranean Diaspora: From Alexander to Trajan (323 BCE-117CE) (Edinburgh: T\&T Clark, 1996).

Bardtke, Hans. "Zusätze zu Esther." In Jüdische Schriften aus hellenistisch-römischer Zeit, vol. 1 Zusätze zu Esther; Zusätze zu Daniel, ed. Hans Bardtke and Otto Plöger, 2nd ed. (Gütersloh: Mohn, 1977), 15-62.

105 Moore, "Origins," 383.

106 Bickerman, "Notes," 253. 
Bellmann, Simon, and Anathea Portier-Young. "The Old Latin Book of Esther: An English Translation." Journal for the Study of the Pseudepigrapha 28 (2019), 417-70.

Bickerman, Elias. "The Colophon of the Greek Book of Esther." In Studies in Jewish and Christian History: A New Edition in English including 'The God of the Maccabees,' vol. 1, ed. Amram Tropper (Leiden: Brill, 2007), 218-37.

Bickerman, Elias. "Notes on the Greek Book of Esther." In Studies in Jewish and Christian History: A New Edition in English including 'The God of the Maccabees,' vol. 1, ed. Amram Tropper (Leiden: Brill, 2007), 238-65.

Bird, Harry W. "L. Aelius Sejanus and his Political Significance." Latomus 28 (1969), $61-98$.

Bond, Helen K. Pontius Pilate in History and Interpretation (Cambridge: Cambridge University Press, 2004).

Borgen, Peder. "Two Philonic Prayers and their Contexts: An Analysis of 'Who is the Heir of Divine Things' (Her.) 24-29 and 'Against Flaccus' (Flac.) 170-75." New Testament Studies 45 (1999), 291-309.

Borgen, Peder. "Philo's 'Against Flaccus' as Interpreted History." In A Bouquet of Wisdom: Essays in Honour of Karl-Gustav Sandelin, ed. Karl-Johan Illman, Tore Ahlbäck, Sven-Olav Back, and Risto Nurmela (Åbo: Åbo Akademi, 200o), 41-57.

Box, Herbert, ed. Philonis Alexandrini "In Flaccum" (London: Oxford University Press, 1939).

Boyancé, Pierre. "Écho des exégèses de la mythologie grecque chez Philon." In Philon d'Alexandrie: Lyon 11-15 Septembre 1966, ed. Roger Arnaldez, Claude Mondésert, and Jean Pouilloux (Paris: Centre Nationale de la Recherche Scientifique, 1967), 169-86.

Cavalier, Claudine. La Bible d'Alexandrie, vol. 12 Esther (Paris: Cerf, 2012).

Champlin, Edward. "Seianus Augustus." Chiron 42 (2012), 361-88.

Clines, David J. A. The Esther Scroll: The Story of the Story (Sheffield: JSOT Press, 1984).

Cohen, Naomi G. Philo's Scriptures: Citations from the Prophets and Writings. Evidence for a Haftarah Cycle in Second Temple Judaism (Leiden: Brill, 2007).

Cohn, Leopold. "Einteilung und Chronologie der Schriften Philos." Philologus, Supplementband 7 (1899), 387-435.

Collins, John J. Between Athens and Jerusalem:Jewish Identity in the Hellenistic Diaspora, 2nd ed. (Grand Rapids: Eerdmans, 200o).

De Troyer, Kristin. The End of the Alpha Text of Esther: Translation and Narrative Technique in MT 8:1-17, LXX 8:1-17, and AT 7:14-41 (Atlanta: Society of Biblical Literature, 2000).

Domazakis, Nikolaos. The Neologisms in 2 Maccabees, Dissertation (Lund University, 2018).

Dorothy, Charles V. The Books of Esther: Structure, Genre and Textual Integrity (Sheffield: Sheffield Academic Press, 1997). 
Earp, John W. “Scripture Index." In Philo, vol. 10 The Embassy to Gaius. Indices to Volumes I-X (Cambridge: Harvard University Press, 1962), 189-268.

Eissfeldt, Otto. Einleitung in das Alte Testament unter Einschluß der Apokryphen und Pseudepigraphen sowie der apokryphen- und pseudepigraphenartigen QumrānSchriften, 3rd ed. (Tübingen: Mohr Siebeck, 1964).

Foster, Samuel S. The Alexandrian Situation and Philo's use of Dike, Dissertation (Northwestern University, 1975).

Fox, Michael V. The Redaction of the Books of Esther: On Reading Composite Texts (Atlanta: Scholars Press, 1991).

Gardner, Anne E. "The Relationship of the Additions to the Book of Esther to the Maccabean Crisis." Journal for the Study of Judaism 15 (1984), 1-8.

Goodenough, Erwin R. By Light, Light: The Mystic Gospel of Hellenistic Judaism (New Haven: Yale University Press, 1935).

Gregg, John A.F. "The Additions to Esther." In The Apocrypha and Pseudepigrapha of the Old Testament in English with Introductions and Critical and Explanatory Notes to the Several Books, ed. Robert H. Charles, vol. 1 Apocrypha (Oxford: Clarendon, 1913), 665-84.

Grimm, Carl L.W. Kurzgefasstes exegetisches Handbuch zu den Apokryphen des Alten Testamentes, vol. 4 Das zweite, dritte und vierte Buch der Maccabäer (Leipzig: Hirzel, 1857).

Hacham, Noah. "3 Maccabees and Esther: Parallels, Intertextuality, and Diaspora Identity." Journal of Biblical Literature 126 (2007), 765-85.

Haelewyck, Jean-Claude. "Le texte dit 'Lucianique' du livre d'Esther. Son étendue et sa cohérence." Le Muséon 98 (1985), 5-44.

Haelewyck, Jean-Claude, ed. Hester. Vetus Latina: Die Reste der altlateinischen Bibel nach Petrus Sabatier neu gesammelt und herausgegeben von der Erzabtei Beuron unter der Leitung von Roger Gryson, 7/3, fascicules 1-5 (Freiburg: Herder, 2003-2008).

Haelewyck, Jean-Claude. "The Relevance of the Old Latin Version for the Septuagint, with Special Emphasis on the Book of Esther." Journal of Theological Studies 57 (2006), 439-73.

Hanhart, Robert, ed. Septuaginta:Vetus Testamentum Graecum, vol. 8.3 Esther, 2nd ed. (Göttingen: Vandenhoeck \& Ruprecht, 1983).

Hennig, Dieter. L. Aelius Seianus:Untersuchungen zur Regierung des Tiberius (München: Beck, 1975).

Hornum, Michael B. Nemesis, the Roman State, and the Games (Leiden: Brill, 1993).

Horst, Pieter W. van der. Philo's "Flaccus": The First Pogrom (Leiden: Brill, 2003).

Jobes, Karen H. The Alpha-Text of Esther: Its Character and Relationship to the Masoretic Text (Atlanta: Scholars Press, 1996). 
Jobes, Karen H. "How an Assassination Changed the Greek Text of Esther." Zeitschrift für die alttestamentliche Wissenschaft 110 (1998), 75-78.

Johnson, Sara Raup. Historical Fictions and Hellenistic Jewish Identity: Third Maccabees in Its Cultural Context (Berkeley: University of California Press, 2004).

Jung, Franz. $\Sigma$ STHP: Studien zur Rezeption eines hellenistischen Ehrentitels im Neuen Testament (Münster: Aschendorff, 2002).

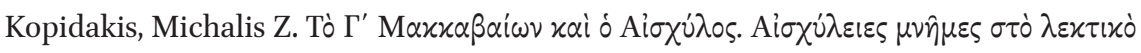

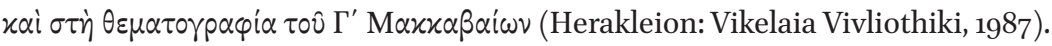

Kottsieper, Ingo. "Zusätze zu Ester." In Das Alte Testament Deutsch, Apokryphen, vol. 5 Das Buch Baruch; Der Brief des Jeremia; Zusätze zu Ester und Daniel, ed. Odil Hannes Steck, Reinhard G. Kratz, and Ingo Kottsieper (Göttingen: Vandenhoeck \& Ruprecht, 1998), 109-208.

Kraus, Wolfgang, and Martin Karrer, eds. Septuaginta Deutsch: Das griechische Alte Testament in deutscher Übersetzung, 2nd ed. (Stuttgart: Deutsche Bibelgesellschaft, 2010).

Leisegang, Johannes. "Index locorum Veteris Testamenti, quos Philo in libris suis graeca lingua scriptis aut adfert aut interpretatur." In Philonis Alexandrini opera quae supersunt, vol. 7.1 Indices ad Philonis Alexandrini opera, ed. Leopold Cohn and Paul Wendland (Berlin: De Gruyter, 1926), 27-43.

Magliano-Tromp, Johannes. "The Relations between Egyptian Judaism and Jerusalem in Light of 3 Maccabees and the Greek Book of Esther." In Feasts and Festivals, ed. Christopher Tuckett (Leuven: Peeters, 2009), 57-76.

Maier, Paul L. "Sejanus, Pilate, and the Date of the Crucifixion." Church History 37 (1968), 3-13.

Marshall, Jonathan. Jesus, Patrons, and Benefactors: Roman Palestine and the Gospel of Luke (Tübingen: Mohr Siebeck, 20o9).

Martin, Raymond A. "Syntax Criticism of the LXX Additions to the Book of Esther." Journal of Biblical Literature 94 (1975), 65-72.

Meiser, Martin. "Gattung, Adressaten und Intention von Philos 'In Flaccum.'” Journal for the Study of Judaism 30 (1999), 418-30.

Mendelson, Alan. "Philo's Dialectic of Reward and Punishment." Studia Philonica Annual 9 (1997), 104-25.

Metzger, Bruce M.Manuscripts of the Greek Bible:AnIntroduction to Greek Palaeography (New York: Oxford University Press, 1981).

Modrzejewski, Józef. “The $\pi$ pó $\tau \tau \alpha \gamma \mu \alpha$ in the Papyri." Journal of Juristic Papyrology 5 (1951), 187-206.

Moore, Carey A. "On the Origins of the LXX Additions to the Book of Esther." Journal of Biblical Literature 92 (1973), 382-93. 
Moore, Carey A. Daniel, Esther, and Jeremiah: The Additions (Garden City: Doubleday, 1977).

Motzo, Raimondo B. "La storia del testo di Ester." In Ricerche sulla letteratura e la storia giudaico-ellenistica, ed. Fausto Parente (Roma: Centro Editoriale Internazionale, 1977), 213-16.

Motzo, Raimondo B. "L'autore e il tempo del rifacimento greco di Ester." In Ricerche sulla letteratura e la storia giudaico-ellenistica, ed. Fausto Parente (Roma: Centro Editoriale Internazionale, 1977), 239-48.

Motzo, Raimondo B. "Il rifacimento greco di Ester." In Ricerche sulla letteratura e la storia giudaico-ellenistica, ed. Fausto Parente (Roma: Centro Editoriale Internazionale, 1977), 273-79.

Motzo, Raimondo B. "Il rifacimento greco di Ester e il III Maccabei." In Ricerche sulla letteratura e la storia giudaico-ellenistica, ed. Fausto Parente (Roma: Centro Editoriale Internazionale, 1977), 283-301.

Niehoff, Maren R. Philo of Alexandria: An Intellectual Biography (New Haven: Yale University Press, 2018).

Nock, Arthur D. "Soter and Euergetes." In Essays on Religion and the Ancient World, ed. Zeph Stewart, vol. 2 (Oxford: Clarendon, 1972), 720-35.

Parker, David C. “Codex Vaticanus." In Anchor Bible Dictionary, ed. David N. Freedman. 6 vols. (New York: Doubleday, 1992), 1:1074-75.

Passoni Dell'Acqua, Anna. "Gli editti di liberazione nella letteratura giudaicoellenistica: intento storico ed apologetico." Materia giudaica 7 (2002), 55-65.

Passoni Dell'Acqua, Anna. “The Liberation Decree of 'Addition' E in Esther LXX: Some Lexical Observations Starting from a New Papyrus (POxy LXVI [sic; read LXV], 4443). New Evidence for the 'Egyptian flavour' of this 'Addition." Adamantius 10 (2004), 72-88.

Pelletier, André, trans. and ed. In Flaccum (Paris: Cerf, 1967).

Pucci Ben Zeev, Miriam. Jewish Rights in the Roman World: The Greek and Roman Documents Quoted by Josephus Flavius (Tübingen: Mohr Siebeck, 1998).

Rostovtzeff, Michael I. "Pax Augusta Claudiana." Journal of Egyptian Archaeology 12 (1926), 24-29.

Royse, James R. "The Works of Philo." In The Cambridge Companion to Philo, ed. Adam Kamesar (Cambridge: Cambridge University Press, 2009), 32-64.

Runia, David T. "Verba Philonica, АГА $А$ МАТОФОРЕIN, and the Authenticity of the 'De Resurrectione' Attributed to Athenagoras.' Vigiliae Christianae 46 (1992), 313-27. Ryle, Herbert E. Philo and Holy Scripture: or, The Quotations of Philo from the Books of the Old Testament (London: Macmillan, 1895).

Siegfried, Carl. Philo von Alexandria als Ausleger des Alten Testaments (Jena: Dufft, 1875). 
Silverstein, Adam J. Veiling Esther, Unveiling Her Story: The Reception of a Biblical Book in Islamic Lands (Oxford: Oxford University Press, 2018).

Smallwood, Edith M. "Some Notes on the Jews under Tiberius." Latomus 15 (1956), 314-29.

Smallwood, Edith M., ed. Philonis Alexandrini “Legatio ad Gaium”(Leiden: Brill, 1961).

Stein, Edmond. "Un essai d'adaptation de la fête de Pourim dans l'Alexandrie hellénistique." Revue des études juives 99 (1935), 109-18.

Sterling, Gregory E. "Recherché or Representative? What is the Relationship between Philo's Treatises and Greek-speaking Judaism?" Studia Philonica Annual 11 (1999), 1-30.

Tcherikover, Victor A., Alexander Fuks, and Menahem Stern, eds. Corpus Papyrorum Judaicorum. 3 vols. (Cambridge: Harvard University Press, 1957-1964).

Torrey, Charles C. "The Older Book of Esther." Harvard Theological Review 37 (1944), 1-40.

Tov, Emanuel. "The LXX Translation of Esther: A Paraphrastic Translation of MT or a Free Translation of a Rewritten Version?" In Empsychoi Logoi: Religious Innovations in Antiquity. Studies in Honour of Pieter Willem van der Horst, ed. Alberdina Houtman, Albert de Jong, and Magda Misset-van de Weg (Leiden: Brill, 2008), 507-26.

Wynn, Kerry H. The Socio-Historical Contexts of the Recensions of Esther, Dissertation (Southern Baptist Theological Seminary, 199o).

Zeitlin, Solomon. "Did Agrippa Write a Letter to Gaius Caligula?" Jewish Quarterly Review 56 (1965), 22-31. 